Preprint

\title{
Civil society in Kono District, Sierra Leone: Capacity, constraints, and potential to contribute to local Sustainable Development Goals
}

\author{
Sahr Otto Fasuluku ${ }^{1}$
}

\begin{abstract}
This study examines the organisational capacity and constraints of civil society organisations (CSOs) in Kono District, Sierra Leone and their potential to deliver the Sustainable Development Goals (SDGs) there. Capacity was found to be very low, with major constraints both internal and external preventing capacity growth and effectiveness. These included poor internal systems and member cooperation, external financial and in-kind dependency, power and politics within and without CSOs, communities' fear of speaking to power and therefore their abdication of roles as checks and balances to hold leaders to account. Several options are available to CSOs, councils and chiefs to address Kono's effectiveness at delivering the SDGs for Kono.
\end{abstract}

Keywords: CSO, Civil Society, organisational capacity, advocacy, monitoring, service delivery, empowerment, elite power, political co-option, bifurcation, Kono, Sierra Leone, Sustainable Development Goals, rural, localisation, trust, decentralisation, neopatrimonialism, bottom-up, indirect-rule, praxis

Acknowledgements: My thanks to Joseph T Gandi and his team in Sierra Leone for translations into Kono and Krio, Berns K Lebbie of NMJD for his advice, guidance, and map of Kono, all the research team in Kono district for their difficult multiple treks to the outer regions of Kono, in particular Tamba Kanawa, Tamba Nelson Jimissa, Sahr E Mbayo and to those lecturers, students and graduates in Fourah Bay College who answered the call.

The original version of this dissertation was submitted in partial fulfilment of the requirements for the MSc in Sustainable Development of the University of London School of Oriental and African Studies (SOAS), Centre for Development, Environment and Policy (CeDEP) on 17th September 2018.

\footnotetext{
${ }^{1}$ Sahr O Fasuluku LL.B, MSc. email: sahrfas@yahoo.co.uk, LinkedIn: https://uk.linkedin.com/in/sofasuluku, Twitter: sahrfas
} 


\section{Civil society in Kono District, Sierra Leone: Capacity, constraints, and potential to contribute to local Sustainable Development Goals}

\section{Introduction}

This study aimed to present data on the current state of capacity of civil society groups and organisations in or working for Kono District, discover internal and external constraints experienced by these CSOs and assess whether the post war constraints referred to in previous national studies still existed and whether they applied to CSOs operating in or advocating on behalf of the Kono District.

The study also aimed to explore whether constraints affecting civil society organisations' effectiveness in the Kono district could be mitigated and whether this could increase their viability to capacity build, become effective programme-ready development agents and partner with other providers to deliver the SDGs in Kono District. The objective was to answer the question: "Can mitigating constraints on civil society in Kono District increase its potential for building its capacity and providing strong advocacy and progress towards localised Sustainable Development Goals?"

The Kono District in the Eastern Province of Sierra Leone is one of the least developed parts of the country, suggesting its Human Development Index (HDI) is lower than the country's average. In 2016 this was 0.420 (0.262 inequality adjusted), ranking 179 out of 188 countries (UNDP, 2016, p4). Kono District's area is $5,640 \mathrm{~km}^{2}$, with a conservative assessment of population at 506,000 (GoSL, 2015, p15). Kono is home to the indigenous minority ethnic group; the Kono tribe, along with a multi-ethnic population. It is the country's primary source of diamonds.

Since independence, the Kono district experienced political and police suppression, poverty, chronic underdevelopment, environmental degradation and the 'resource curse'. Several external factions fought over the district during the 1990s leaving it decimated. Most citizens became internally displaced persons or refugees, some returned after the conflict.

Most NGOs and civil society organisations (CSOs) in Sierra Leone operate $342 \mathrm{~km}$ away in Freetown. In 2016 over 100 CSOs were registered with the Kono District Council. Prior to this study most CSOs were believed to have low organisational and delivery capacity. Civil society activity was reputed to be semi-dormant with high levels of political co-option, elite capture, poor governance, CEO dominance of boards, corruption and poor partnership activity.

Community power relations were reported to be significant in maintaining power holders' positions and perpetuating disempowerment. Networks were reportedly undemocratic and self-serving instead of empowering their CSO members; which reduced their collective voice. Kono CSO rights-advocacy was reputed to be largely absent as CSOs focused on contracts and were said to be disconnected from stakeholders. This affected public and donor trust of CSOs and prevented working partnerships for local sustainable development.

\section{Literature Review}

This review was limited to published and unpublished works and media on issues pertinent to Kono District and Sierra Leonean civil society. The focus was on civil society's capacity, power relations, funding, enabling environment, and potential to contribute to the Global SDGs and human/indigenous rights in Kono District. It does not address the impacts or nature of civil society or whether it is an imported or indigenous concept.

There was very little literature on Kono District's civil society and Kono people. What was available focused on diamond mining, the resource curse (Johnston-Taylor, 2015), conflict, chiefs, elite (Albrecht, 2017; Fanthorpe and Maconachie, 2010) and rural livelihoods (Bateman 2017; Binns 1980). 
Studies relating to Sierra Leonean civil society were at national or African regional level and did not disaggregate findings to subnational levels. Themes like conflict, post-conflict development and peace-building dominated discourses, with many attempts to link the conflict to Sierra Leone's lack of progress.

In contrast with this narrative, some literature acknowledged the resurgence of pre-conflict social norms and power politics including; colonial-style legislation and indirect rule. Erdmann and Engel (2007, p26) noted neo-patrimonialism, patronage, clientelism, rent-seeking, a rentier state and gerontocracy, that paralysed civil society and sustainable development (2007).

Many studies debated the nature of civil society and whether it was imported or indigenous, notwithstanding the long traditions of community praxis ${ }^{2}$ in Africa.

Literature was scant on the SDGs relating to Sierra Leonean civil society, and localising SDGs. However, the Global Taskforce of Local and Regional Governments stated its commitment to local councils as agents for localising SDGs in partnership with civil society and other stakeholders (GTLRG 2018).

The CIVICUS studies on civil society (CGG, 2007, 2014) were widely cited. Key findings of CIVICUS 2007 were that CSOs in Sierra Leone had low organisational capacity and did not practice good governance and gender equity. They had a culture of secrecy and corruption, and lacked internal democracy, accountability and transparency. CSOs were sometimes family organisations set up to attract funding, and their founders monopolised leadership. Some CSOs in Sierra Leone actively met the population's key social needs and $87 \%$ of community survey respondents felt CSOs provided better services than the state (CGG, 2007). The study did not appear to reach Kono District during data collection.

The 2007 study reflected respondents' perceptions of tempered optimism and an upward civil society trend, however, its data had been collected between 2004 - 2006; two to four years after the end of the Sierra Leone conflict. This was during the UN departure, during unprecedented international investment into peacebuilding, decentralisation, democracy-building, civil society capacity-building and attitude change. This may have biased survey responses, while in practice society was retrenching pre-war corruption and patrimonialism (Datzberger, 2014).

During the post 2010 period, optimism continued. Fanthorpe and Maconachie (2010) proposed that the downturn of mining and resurgence of agriculture presented CSOs with opportunities, but paradoxically argued that governance and economic improvements had to come before CSO activity (rather than after, or because of it). Kanyako (2011) highlighted that fundraising diversification opportunities existed for CSOs. However, taking advantage of such opportunities is challenging for isolated marginalised Kono communities and requires capacity in itself.

Labonte (2011) revealed that the UN and international NGOs (INGOs) were aware of elite capture of local development resources, capture of civil society and of local councils in Sierra Leone. The very process of decentralisation could increase elite capture and disempowerment of local non-elites as CSOs' founders aimed to appease power holders. The UN's elite-capture mitigation strategy had been to co-opt elites, but this led to a feeding frenzy of elites competing for peace-building resources (Labonte). Similar scenarios were witnessed in Kono District and Freetown; project bidding became a full-time occupation while questions remain about how many were delivered to rural communities.

Labonte states that in contrast, the INGOs' preferred strategy was to attempt transformation of elite /non-elite relations, encouraging cultural change (2011). This then raises questions about their levels of success in Kono District. "Elites are likely to capture resources and accrue self-benefits

\footnotetext{
${ }^{2}$ Action learning by doing. action oriented towards changing society August Cieszkowski (1838) Prolegomena zur Historiosophie
} 
disproportionately when the institutions in which they operate lack internal or external controls, monitoring mechanisms, or oversight." this would require mitigation of endemic elite/non-elite power imbalances and attitudinal change (Labonte, 2011).

The CIVICUS 2014 follow-up Rapid Assessment presented little additional information, relying heavily on data from CIVICUS 2007 and an updated literature review. It interviewed about 30 CSOs in the Eastern Province (CGG, 2014) but didn't specify how many were from Kono district.

Datzberger's (2014) in-depth study of power and neopatrimonialism in Sierra Leone in relation to civil society noted "Sierra Leone's civil society landscape appears to be neutralised, depoliticised if not instrumentalised to provide social services the state is either too weak or unwilling to deliver." (Datzberger, p3). This argument asserts that heads of CSOs had voluntarily given up on advocacy in the hope of securing favour and funding, avoiding disfavour and delivering social services.

The 'bifurcated state' described by Datzberger is as easily recognisable in Sierra Leone as it is in many other countries, where displaying and even strongly speaking for one behaviour publicly, exists simultaneously with practising and promoting an opposite behaviour privately. In addition, given the overriding and undermining effects of neopatrimonialism and the urban-rural divide, it is not hard to agree that civil society participation and democracy cannot survive them (Datzberger). She, and other authors e.g. Acemoglu et al (2014), have argued that colonial effects in Sierra Leone still survive, which include indirect rule through local power holders, institution capture, and minority monopolisation of wealth and power alongside majority poverty. Datzberger also argued that people's ability (or empowerment) to take part in bottom-up activism and agency depended on their human development and education, which was neglected in peace building and development discourses. This is highly relevant to this study.

The African Civil Society Circle (ACSC) (2016) Position Paper warned that governments could not hope to fulfil the SDGs on their own; that inclusion of civil society and other sectors was imperative for localisation of the SDGs and their success. It proposed four key areas where civil society must work to localise the SDGs in Africa; advocacy, holding to account, service delivery and monitoring SDGs locally. The UN's post-2015 global citizens' consultation had revealed strong demands for full involvement of civil society in policymaking, advocacy and mediation (ACSC). In the same year the joint Sierra Leonean CSOs' Position Paper on SDG Implementation entitled "Walk the Talk" (2016, in GoSL 2016, p55) was annexed in the government's Advanced Draft Report on Adaptation of the Goals in Sierra Leone" and submitted to the UN HLPF on Sustainable Development. The CSO's position paper called for social accountability, clear strategies for inclusion of civil society and communities in SDG implementation, monitoring, and deeper community engagement (2016). Beekman et al (2015), Omede (2014) and Ibrahim and Majeks-Walker (2015, p165) of the West Africa Civil Society Institute (WACSI) while acknowledging many constraints faced by civil society in Liberia, Sierra Leone and Nigeria concurred that CSOs were vital for Africa's political, social and economic development, and had been effective in development and nation building, holding to account and providing services. During the ebola epidemic:

"CSOs and NGOs had the potential to reach places where the government could not come. In Sierra Leone CSOs had trouble being recognised as valuable partners in the Ebola response. However, once they were involved, different approaches to reach communities in order to encourage knowledge and behaviour change, were valued." (Beekman et al, 2015)

As of 2016, Sierra Leone's fairly high IIAG rating for participation and human rights was 63/100 (improving) (Mo Ibrahim Foundation 2017), although there were 'warning signs' for overall governance. This was higher than West Africa's average of 57/100 (improving) where several countries were slowing or deteriorating (Mo Ibrahim Foundation 2017). However, Sierra Leone's rating should be treated with caution as subsequent events reflected the reality of its enabling environment. In January 2018 the government imposed new NGO barriers; to assembly, to advocacy, 
to activities and to entry; including requirements to have office space, a bank account, signboard and at least 5 staff before registering. Other requirements were to sign undertakings to government for inspections and re-registration every two years (ICNPL, 2018). Civil society groups were to have a budget ceiling of Le500 million ( $£ 50,000)$, not register as an NGO and be "exclusively engaged in activities at sub-district level" (OHCHR, 2018). The restrictions;

\section{"impinge on the exercise of the rights to freedom of expression and freedom of association which are guaranteed under international human rights law, in particular under article 19 and 22 of the International Covenant on Civil and Political Rights." (OHCHR, 2018).}

As of 27 July 2018, CIVICUS' live online rating of civil society space in Sierra Leone was: "Obstructed" (2018).

This literature review highlights a need in Sierra Leone and Kono District for identification and mitigation of embedded CSO constraints. It also highlights a need for stakeholders' to carry out their own exploration of alternative relationships; between communities, Kono district CSOs, local councils, Paramount chiefs and central government. The review illustrates a need to mitigate fears, prejudices, behaviours and attitudes, amongst local elite and non-elite, that obstruct sustainable development in Kono district.

Given CSOs" underexploited "sine qua non relevance" (Omede, 2014) to delivering the SDGs; CSO capacity-building in Kono district will require crosscutting studies of localisation at District and chiefdom level that cover every sector of sustainable development and link Kono CSOs indelibly to the SDGs and to human/ indigenous rights-advocacy in the district.

\section{Materials and methods}

For this study, civil society was deemed to be; communities and individuals organising themselves for praxis and rights advocacy, outside of political, family, state agencies or businesses, that aimed to perform a social or sustainable development function to improve society.

Mixed methods were used to explore civil society in Kono District, its constraints and potential for assisting delivery of the SDGs, using naturalistic ontology, a mixture of positivistic quantitative, interpretive qualitative, and critical research methods. The study was influenced by emancipatory action research as advocated by Paolo Friere $(1968,1993)$ exploring systemic and internalised oppression.

Purposive sampling was used to target those most knowledgeable about CSOs within their communities in each of Kono's 14 chiefdoms. Part of this study quantitatively assessed a broad range of CSOs capacities in Kono district to provide district (and potentially chiefdom) level baselines for future longitudinal monitoring, to provide triangulation for qualitative discussions and to verify whether national level findings about CSO capacity in previous years' literature were evident at chiefdom and district level in Kono district today.

The rest of the study was based to some extent in grounded theory, and focused on qualitative discovery, using open ended questionnaires with respondents to generate some theories from experiences, and open up ideas for future investigation of civil society in Kono district.

Several frameworks were considered for measuring CSO capacity, including the CIVICUS methodology, which was not practicable or relevant for immediate localised practical action by Kono CSOs. However, the Critical Ecosystem Partnership Fund (CEPF) Organisational Capacity tool and Gender Tracking tool in Excel (undated) were suitable. These were derived by CEPF from the PROSE, IDF, TNC NGO self-assessment tool, from a scorecard methodology, from lessons learnt from the World Bank/WWF Alliance effectiveness tracking tool, CIVICUS CSI-SAT, GCSI, IDF, 
etc. BOND's Health Check 11 pillars (undated) also informed additional questions on learningculture.

The second questionnaire was created bespoke for this study for qualitative explorations of constraints and SDG awareness.

An Ethics review was supervised by the Centre for Development Environment and Policy (CeDEP) at SOAS and undertakings were made to protect respondents' data, identity and safety and to ensure interviewers' safety (Appendix 1).

The recruitment of volunteers took place in Freetown and Kono, however limited resources and time meant the Kono team, who had research experience with a variety of NGOs took the lead and provided training to local interviewers.

Excel questionnaires were abandoned due to shortage of laptops, and surveys were migrated to the ODK platform at the suggestion of Kono interviewers using Kobo Toolbox and Kobo Collect (Appendix 8 and 9). This was fully functional away from data signals and downloadable in Kono district from Google Play, it was usable on mobile phones with no data signal, and was GIS enabled. With the addition of battery packs, this ensured several days mobile phone charge in remote chiefdoms.

The team were supplied with an interviewer's manual (some sections modified from Fulu and Jewkes (2007)), which empowered them to collaborate in participatory training, and we held team meetings internationally on WhatsApp. Data was particularly expensive for the team there due to disproportionately higher data charges in Sierra Leone, a phenomenon which impedes international collaboration, participatory development and exacerbates the digital divide. During fieldwork, all teams travelled on motorbikes.

\section{Mapping}

For mapping, 6 interviewers travelled to 13 out of the 14 Kono chiefdoms (Figure 1, Appendix 3). Enumerators made contact with village communities, elders and chiefs in randomly selected towns within chiefdoms and in chiefdom headquarter towns. Out of 236 CSO contacts; 105 female and 127 male, over 182 initially agreed to be respondents in the forthcoming study, gave their details and signed respondent consent forms (Appendix 1). 


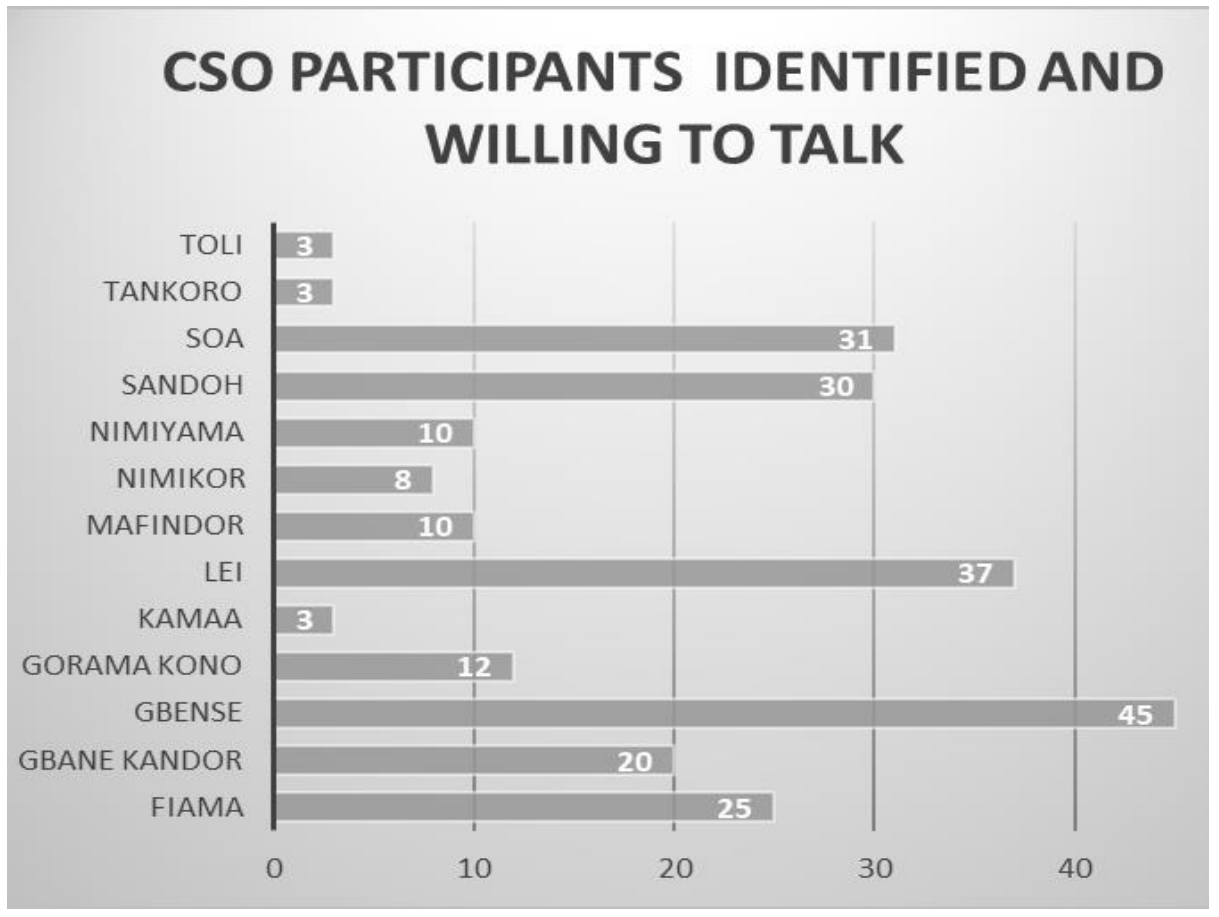

Figure 1 Participants Identified as willing to talk during mapping, author field research, 2018

\section{Sampling}

The total population of CSOs and CSO participants and beneficiaries in Kono District was unknown. Random sampling was difficult due to the absence of a reliable sample frame. Purposive sampling was carried out, with the sample list divided into four subgroups in each chiefdom:

1. Chair/CEO,

2. Executive/board/committee,

3. Member/volunteer/staff,

4. Marginalised/beneficiary.

People in the Chair/CEO category were overrepresented in proportion to the other groups and the "marginalised/ beneficiary/ community" subgroup initially appeared very underrepresented (Figure 2). However rural respondents explained that they were also CSO beneficiaries, marginalised and part of the community, belonging to more than one subgroup.

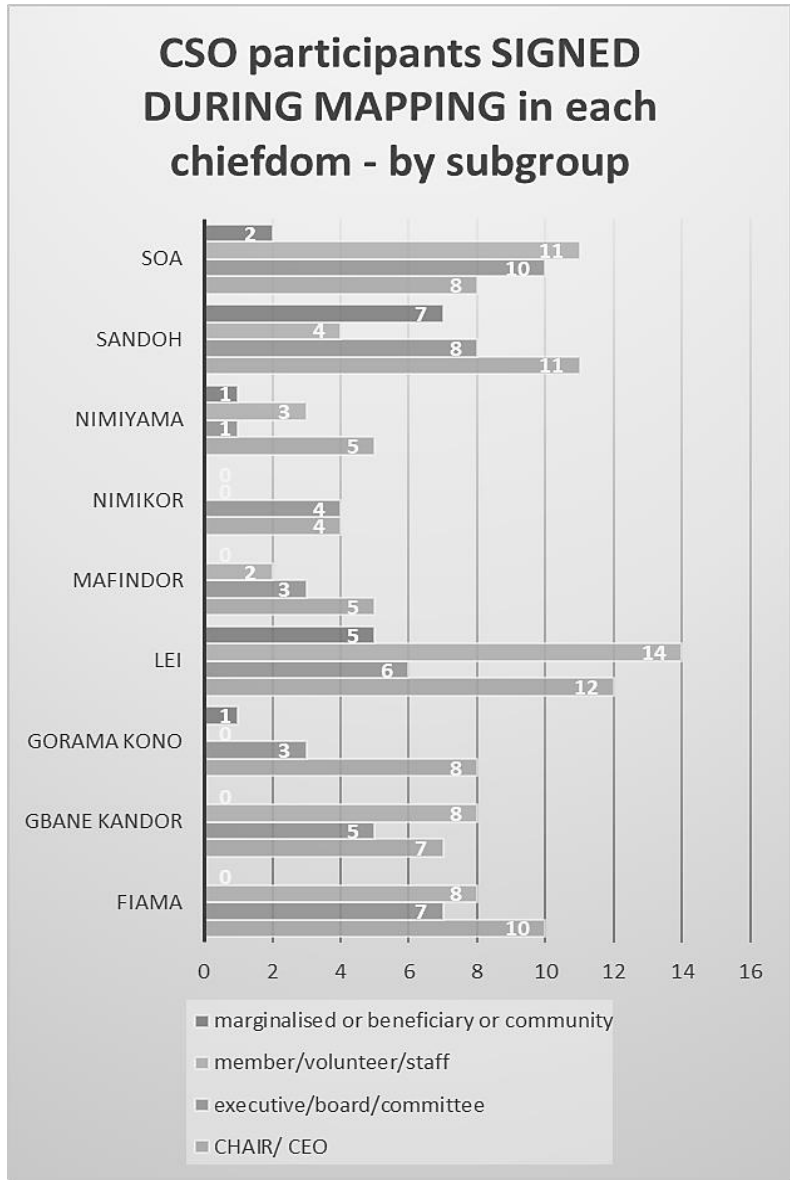


Respondents in each subgroup were enumerated and selected using a random number generator.

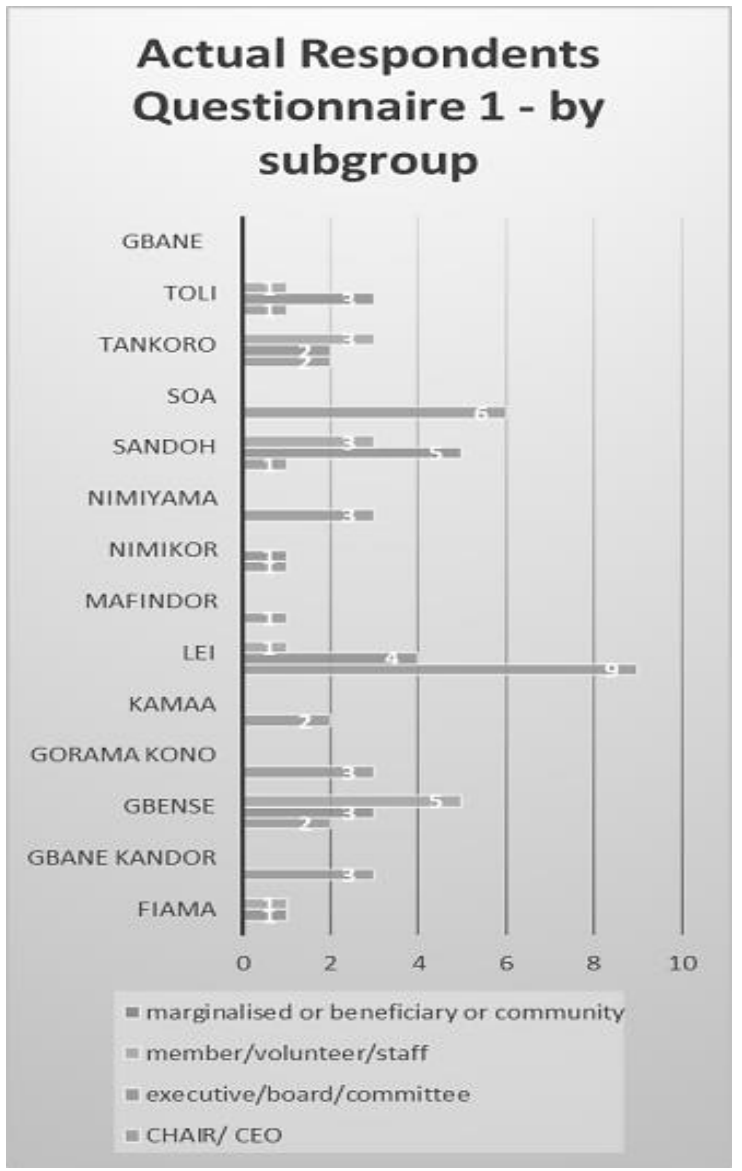

Figure 3 Actual respondents - Questionnaire 1 by subgroup, author - field research, 2018
Figure 2 CSO participants signed during mapping in each chiefdom by subgroup, author, field research 2018

\section{Data collection}

On the interview days, only $\mathbf{4 8}$ out of the $\mathbf{1 8 2}$ mapped respondents were in town and completed interviews. Consequently, a further $\mathbf{4 2}$ respondents were recruited on interview days by canvassing the areas and getting referrals.

The team of 10 enumerators submitted data in real time into their mobile phones using the Kobo Collect App. Numerators completed over 70 Q1 questionnaires (Appendix 7) comprised of 35 multiple choice questions on capacity and gender with skip logic, in 14 chiefdoms. A further 58 structured Q2 questionnaires (Appendix 8) comprised of 27 open ended questions and subquestions on constraints and SDGs, were completed in 9 chiefdoms. Only one respondent in a Diaspora Kono CSO completed interviews.

A coding error (re CSO mission statement) led to spoilt results on all responses for that question. 


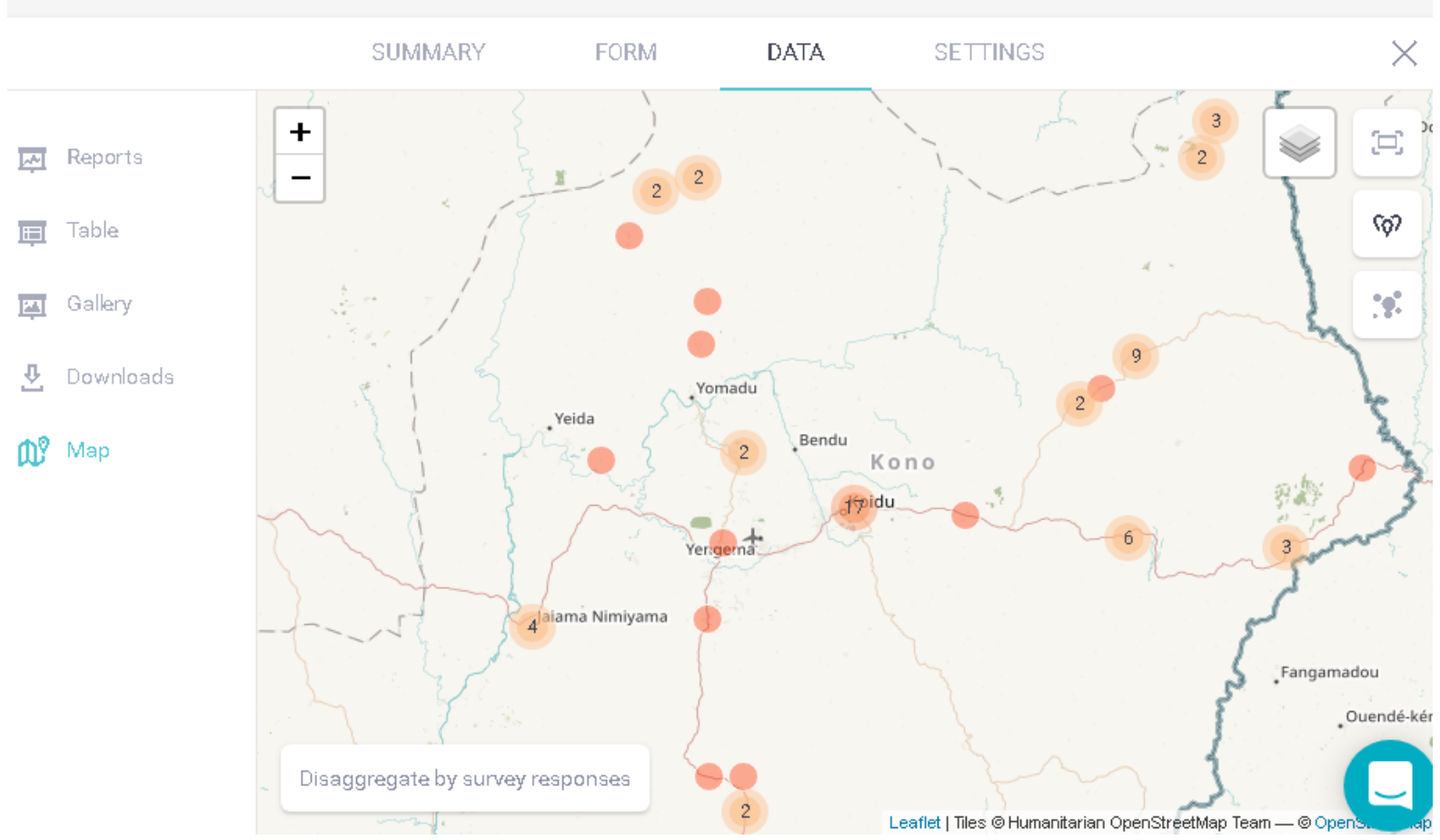

Figure 4 Questionnaire 1 GPS locations, generated on Humanitarian OpenStreetMap Team, 2018

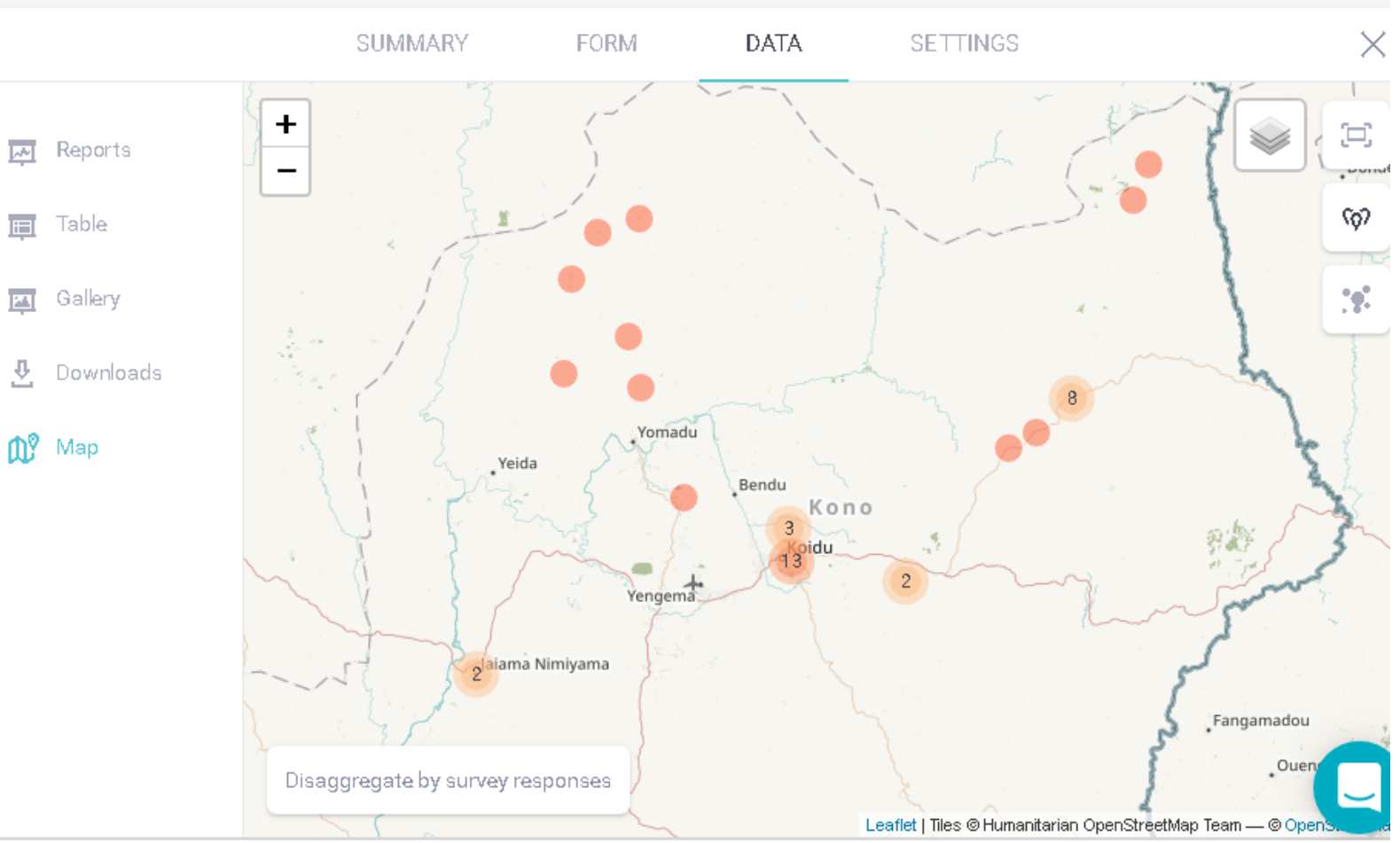

Figure 5 Questionnaire 2 GPS locations, generated on Humanitarian OpenStreetMap Team, 2018 


\section{Demographics}

Over $73 \%$ of CSO respondents interviewed, and their target beneficiaries, lived and worked in rural locations away from Koidu city; the district capital. Figure 6 shows $68 \%$ of respondents' highest education level was secondary school certificate or lower. CSO actors' ages were widely distributed.

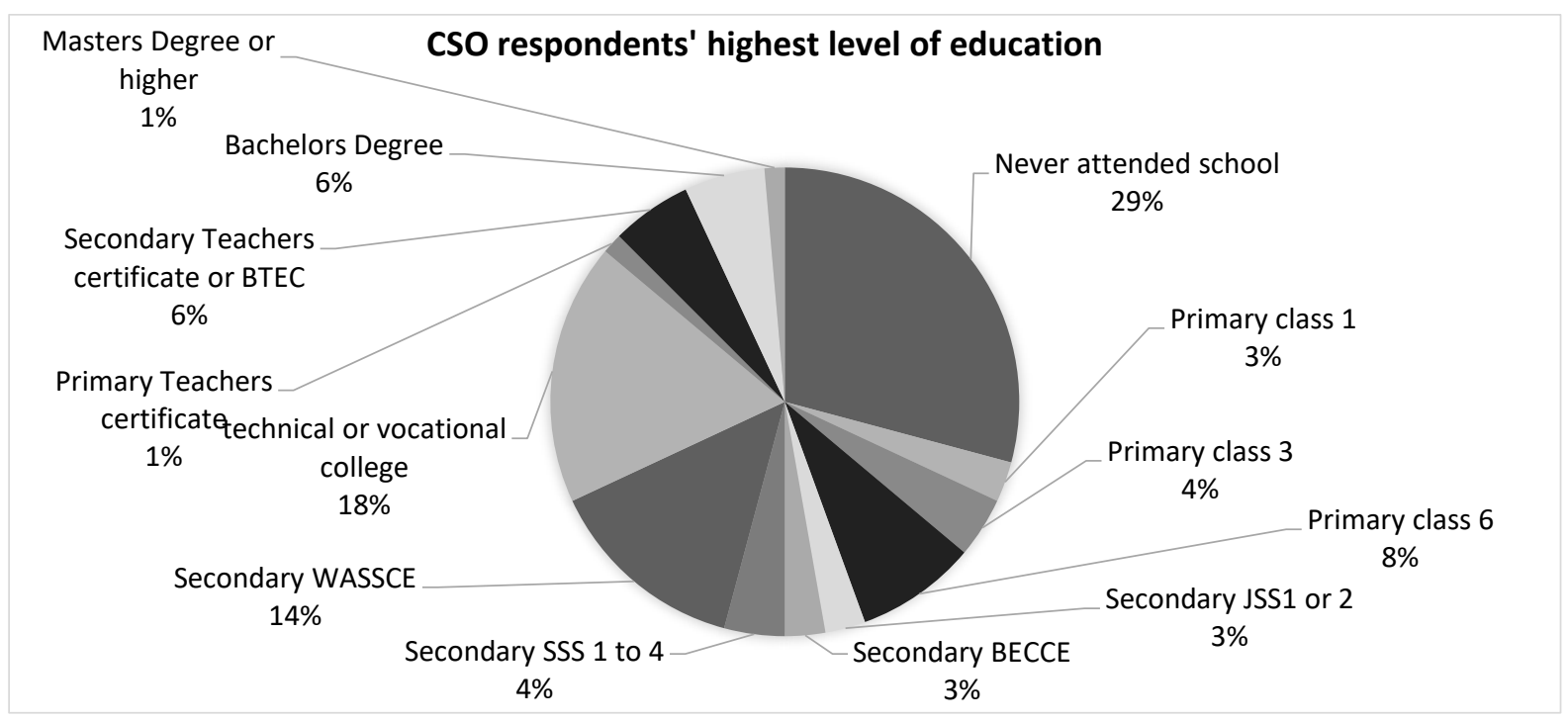

Figure 6 CSO respondents highest level of education, author, field research 2018

\section{Data cleaning}

Data analysis was conducted using excel, SPSS, word and NVivo.

The following variables with substantial missing data were deleted:

- Staff experience in terms of total number of years (30\% don't knows) - feedback from interviewers indicated those who did provide an answer did not have reliable information on this variable.

- Annual governance budget (56\% don't knows) - in addition, some outliers were very high, suggesting misunderstanding of the question as required income rather than actual money used per annum - there was an alternative related question covering financial capacity elsewhere.

- Development of mission statement

\section{Testing data distribution of quantitative data (Questionnaire 1)}

For sample characteristics, Shapiro Wilk tests (Shapiro and Wilk, 1965) were conducted in SPSS on all variables' characteristics, and visual inspection of histograms, box plots and QQ plots, was also done, using the following independent variables; 'gender', 'organisation type', 'respondents CSO subgroup', and 'respondents' usual location'. These variables were chosen as representing a broad cross section of sizes of CSO, stratification and gender of participants and their geography.

Most data were skewed and kurtotic with gender the highest (skewness ranged from -4.051 with 0.393 $\mathrm{SE}$, and kurtosis from 15.0 with 1.121 SE with $\mathrm{z}$ scores well outside the -1.96 to +1.96 bracket and $\mathrm{p}$ values < 0.05). 'Organisation type' was not as skewed or kurtotic, but $\mathrm{p}<0.05$ in almost every characteristic, for 'respondent location' this fell to $87 \%$ of characteristics.

Using listwise exclusion of missing data added bias, leaving insufficient samples. Pairwise exclusion increased sample size to $100 \%$ and reduced skewness. For $88 \%$ of 500 variable characteristics, $p$ $<0.05$ with improved kurtosis and skewness z scores, $86 \%$ were within -1.96 to +1.96 . This meant 
(when using pairwise exclusion where SPSS permitted) keeping the null hypothesis that data was approximately normally distributed.

\section{Results}

\section{Questionnaire 1 - Quantitative - Organisational Capacity}

\section{Civil Society Organisations' Scores}

On a scale where 4 indicated high capacity, 0 indicated non-existent capacity and 1 indicated very low capacity; levels of organisational capacity were assessed and scored in the following areas:

- Human resources,

- Financial resources,

- Management and Learning Cultures,

- Strategic Planning,

- Delivery, and

- Gender tracking

Organisational and gender capacity (mean and median) scores

\begin{tabular}{|c|c|c|c|c|c|}
\hline Capacity & Indicators & Measurement & $\begin{array}{l}\text { score } \\
\text { mean }\end{array}$ & $\begin{array}{l}\stackrel{0}{c} \\
\stackrel{+}{+} \\
\stackrel{+}{\rightarrow}\end{array}$ & 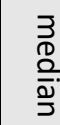 \\
\hline \multirow{4}{*}{$\begin{array}{l}\text { Human } \\
\text { resources } \\
\text { mean } 1.3 \\
\text { median } 1\end{array}$} & Staff numbers & Staff numbers & 0.6 & 4 & 0 \\
\hline & Staff skills & $\begin{array}{l}\text { Skills in; project management, organisation } \\
\text { management, advocacy, SDG action, SDG } \\
\text { communications, SDG apps, stakeholder appraisal, } \\
\text { using GIS }\end{array}$ & 1.8 & 4 & 0 \\
\hline & $\begin{array}{l}\text { Developing human } \\
\text { resources }\end{array}$ & $\begin{array}{l}\text { Existence of staff \& volunteer development plan, } \\
\text { mentoring, training, appraisal and fundraising for hr } \\
\text { development }\end{array}$ & 1.2 & 4 & 1 \\
\hline & Volunteers & Number and standard of management of volunteers & 1.4 & 4 & 1 \\
\hline \multirow{6}{*}{$\begin{array}{l}\text { Financial } \\
\text { resources } \\
\text { mean } 0.9 \\
\text { median } 1\end{array}$} & Financial resources & Ability of CSO to function & 1.2 & 4 & 1 \\
\hline & Funding resources & Number of funding sources & 0.9 & 4 & 0 \\
\hline & $\begin{array}{l}\text { Fundraising } \\
\text { capacity }\end{array}$ & $\begin{array}{l}\text { Extent of ability to prepare realistic proposals, } \\
\text { indicators, logical frameworks }\end{array}$ & 0.8 & 4 & 0 \\
\hline & Sustainable finance & $\begin{array}{l}\text { Extent of development of a long-term sustainable } \\
\text { finance plan and long term financial sources }\end{array}$ & 0.7 & 4 & 1 \\
\hline & $\begin{array}{l}\text { Organisational } \\
\text { profile }\end{array}$ & $\begin{array}{l}\text { Organisational profile in the eyes of stakeholders, the } \\
\text { government and the public }\end{array}$ & 1.1 & 4 & 1 \\
\hline & $\begin{array}{l}\text { Organisation } \\
\text { structure }\end{array}$ & $\begin{array}{l}\text { Extent to which CSO has a well-functioning democratic } \\
\text { board/committee, job descriptions and staff } \\
\text { management and recruitment policies }\end{array}$ & 1 & 4 & 1 \\
\hline
\end{tabular}




\begin{tabular}{|c|c|c|c|c|c|}
\hline Capacity & Indicators & Measurement & $\begin{array}{l}\text { score } \\
\text { mean }\end{array}$ & 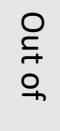 & 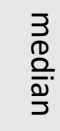 \\
\hline \multirow{5}{*}{$\begin{array}{l}\text { Management } \\
\text { and learning } \\
\text { culture }\end{array}$} & $\begin{array}{l}\text { Administration }(1 \\
\text { point per item / } 2 \text { ) }\end{array}$ & $\begin{array}{l}\text { Existence of admin systems for supplies, equipment, } \\
\text { purchasing, vehicles, grievance, disciplinary, project } \\
\text { processes, operating manual }\end{array}$ & 1.4 & 5 & 0 \\
\hline & $\begin{array}{l}\text { Financial } \\
\text { management }\end{array}$ & Extent to which budgets are obeyed and records kept & 1.4 & 4 & 1 \\
\hline & Financial reporting & $\begin{array}{l}\text { Extent to which Board/committee review regular } \\
\text { publicly published financial reports, annual external } \\
\text { audits }\end{array}$ & 1.0 & 4 & 1 \\
\hline & $\begin{array}{l}\text { Monitoring and } \\
\text { evaluation }\end{array}$ & $\begin{array}{l}\text { Extent that frequent regular Monitoring and eval, } \\
\text { lessons learned are applied to future project design, } \\
\text { published widely }\end{array}$ & 1.4 & 4 & 1 \\
\hline & $\begin{array}{l}\text { Learning culture }(1 \\
\text { point per item /2)) }\end{array}$ & $\begin{array}{l}\text { Openness to new ideas \& questioning, overlapping } \\
\text { teams, knowledge sharing, identifying root causes, } \\
\text { leadership involves all in decision-making, CSO upskills } \\
\text { all }\end{array}$ & 1.5 & 4 & 0 \\
\hline \multirow{5}{*}{$\begin{array}{l}\text { Strategic } \\
\text { planning }\end{array}$} & $\begin{array}{l}\text { Governance board/ } \\
\text { committee }\end{array}$ & $\begin{array}{l}\text { Extent to which Board/committee is democratic not } \\
\text { CEO-controlled, separated roles from management, } \\
\text { diverse board selected for their different backgrounds } \\
\text { and skills }\end{array}$ & 0.5 & 4 & 0 \\
\hline & $\begin{array}{l}\text { Respondents quote } \\
\text { mission statement }\end{array}$ & $\begin{array}{l}\text { Number of respondents who attempted to quote their } \\
\text { mission statement and researcher-allocated estimated } \\
\text { score* in proportion to those that didn't or couldn't }\end{array}$ & 0.5 & 4 & \\
\hline & Strategic planning & $\begin{array}{l}\text { Existence and development of a strategic plan, } \\
\text { regularly updated using participatory process, } 3 \text { years, } \\
\text { clear objectives \& indicators, relevant to beneficiary } \\
\text { needs, relevant to SDGs }\end{array}$ & 1.7 & 4 & 1 \\
\hline & $\begin{array}{l}\text { Relevance to } \\
\text { mission }\end{array}$ & $\begin{array}{l}\text { Extent to which all projects are relevant to each other, } \\
\text { to the mission and to the strategic plan }\end{array}$ & 1.4 & 4 & 1 \\
\hline & Accountability & $\begin{array}{l}\text { Extent to which stakeholders make decisions on design } \\
\text { and implementation of all projects and revision of the } \\
\text { mission and plan }\end{array}$ & 1.2 & 4 & 1 \\
\hline \multirow{4}{*}{$\begin{array}{l}\text { Delivery } \\
\text { mean } 1.5 \\
\text { median } 1.5\end{array}$} & $\begin{array}{l}\text { Relevance to the } \\
\text { SDGs }\end{array}$ & $\begin{array}{l}\text { Extent to which all projects define clear SDG targets or } \\
\text { SDG-advocacy outcomes and monitor progress towards } \\
\text { them }\end{array}$ & 1.1 & 4 & 0 \\
\hline & Delivery efficiency & Proportion of delivery successes and delivery on time & 2.3 & 4 & 3 \\
\hline & $\begin{array}{l}\text { Rural reach and } \\
\text { rural management }\end{array}$ & $\begin{array}{l}\text { Extent to which rural field projects are directed from } \\
\text { local rural field offices, leadership role in rural CSO } \\
\text { network }\end{array}$ & 1.4 & 4 & 2 \\
\hline & $\begin{array}{l}\text { Working with } \\
\text { others }\end{array}$ & $\begin{array}{l}\text { Extent of working relations and on-going joint projects } \\
\text { with other CSOs, leadership role in CSO network }\end{array}$ & 1.0 & 4 & 1 \\
\hline
\end{tabular}


Civil society in Kono District, Sierra Leone - Sahr O Fasuluku

\begin{tabular}{|c|c|c|c|c|c|}
\hline Capacity & Indicators & Measurement & $\begin{array}{l}\text { score } \\
\text { mean }\end{array}$ & $\begin{array}{l}0 \\
\stackrel{0}{+} \\
\text { o } \\
\rightarrow\end{array}$ & $\begin{array}{l}3 \\
\text { 3. } \\
\frac{0}{2} \\
\frac{2}{2}\end{array}$ \\
\hline \multirow{7}{*}{$\begin{array}{l}\text { Gender } \\
\text { tracking } \\
\text { mean } 2 \\
\text { median } 1\end{array}$} & Gender policy & $\begin{array}{l}\text { Extent Gender policy is written AND put into practise in } \\
\text { ALL dealings }\end{array}$ & 2.6 & 3 & 3 \\
\hline & $\begin{array}{l}\text { Gender issues } \\
\text { personnel }\end{array}$ & $\begin{array}{l}1 \text { or more gender staff or volunteer and extent of } \\
\text { training }\end{array}$ & 1.9 & 3 & 1 \\
\hline & Gender training & $\begin{array}{l}\text { Extent of staff training \& FOLLOW-UP training on } \\
\text { gender }\end{array}$ & 2.0 & 3 & 1 \\
\hline & Gender analysis & $\begin{array}{l}\text { Extent that Gender analysis is done during planning for } \\
\text { ALL projects/ programmes }\end{array}$ & 2.1 & 3 & 2 \\
\hline & $\begin{array}{l}\text { Gender project } \\
\text { data gathering }\end{array}$ & $\begin{array}{l}\text { Extent to which projects collect gender-separated data } \\
\text { which are published externally }\end{array}$ & 1.9 & 3 & 1 \\
\hline & $\begin{array}{l}\text { Monitoring gender } \\
\text { difference of } \\
\text { impact of projects }\end{array}$ & $\begin{array}{l}\text { Extent of Monitoring gender difference of impact of } \\
\text { project on males and females for all programmes and } \\
\text { project }\end{array}$ & 2.2 & 3 & 2 \\
\hline & $\begin{array}{l}\text { Gender issues } \\
\text { financial resources } \\
\text { are set aside }\end{array}$ & $\begin{array}{l}\text { Extent Financial resources are set aside to bring in } \\
\text { gender in all programmes and operations }\end{array}$ & 1.8 & 3 & 0 \\
\hline
\end{tabular}

Table 1 Questionnaire 1 Scores (mean and median) for organisational and gender capacity (on scale of 0-4), author, field research, 2018

As indicated by previous CIVICUS Sierra Leone national-level studies; CSO capacity in Kono District was low. On a scale where 4 indicated high capacity, 0 indicated non-existent capacity and 1 indicated very low capacity; mean scores at district level hovered between 0.9 and 2 , while medians were between 1 and 1.5 .

However, at individual organisation level for almost all CSOs a large number of scores for each indicator were 0 or 1 , indicating no, or very low capacity in those areas.

The histograms below (Figures 7 -12), show the distribution of scores at district level. Median scores represented the majority of Kono CSOs more accurately than means. Two organisational strengths were highlighted by median data;

- The proportion of projects delivered successfully and on time, and

- The extent to which a gender policy was developed, written, and put into practise in all dealings.

CSOs said they had moderate capacity for;

- gender analysis carried out during planning for all projects/ programmes,

- monitoring of the different impacts of projects on males and females, and

- rural field projects being directed from local rural field offices with CSOs in leadership roles in a rural CSO network. 


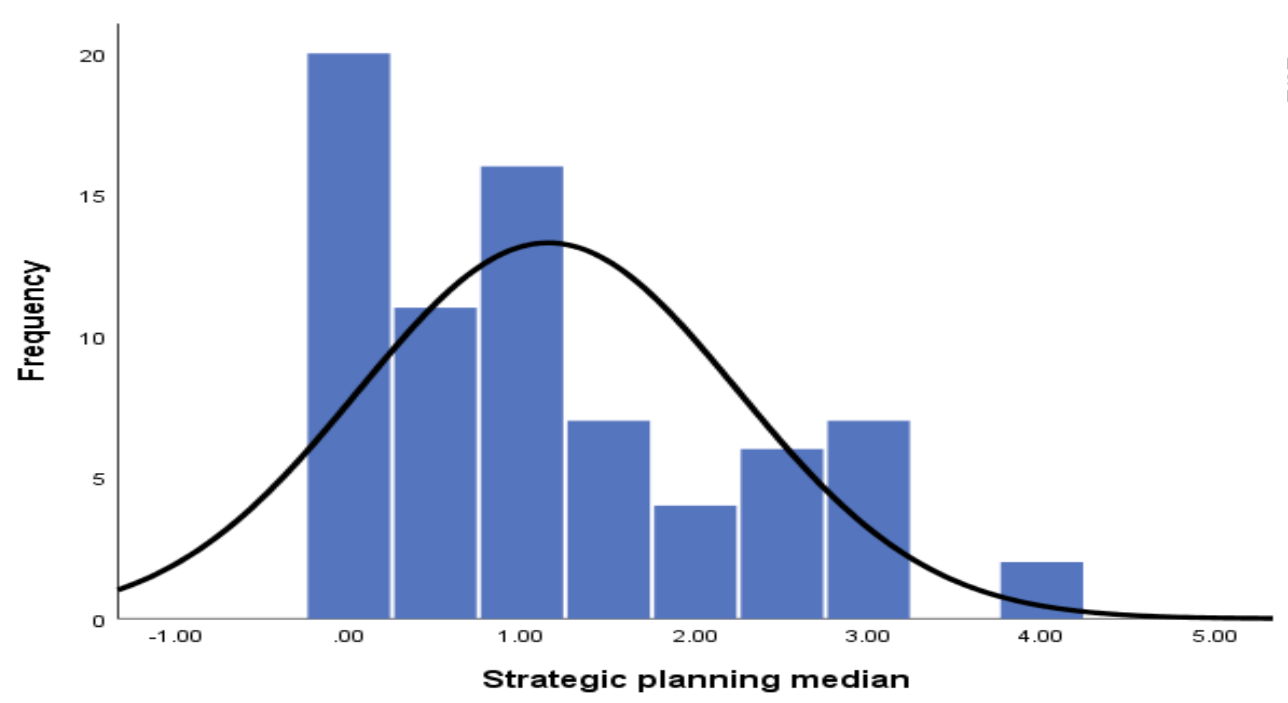

Figure 7 Strategic planning capacity median histogram, author, field research, 2018

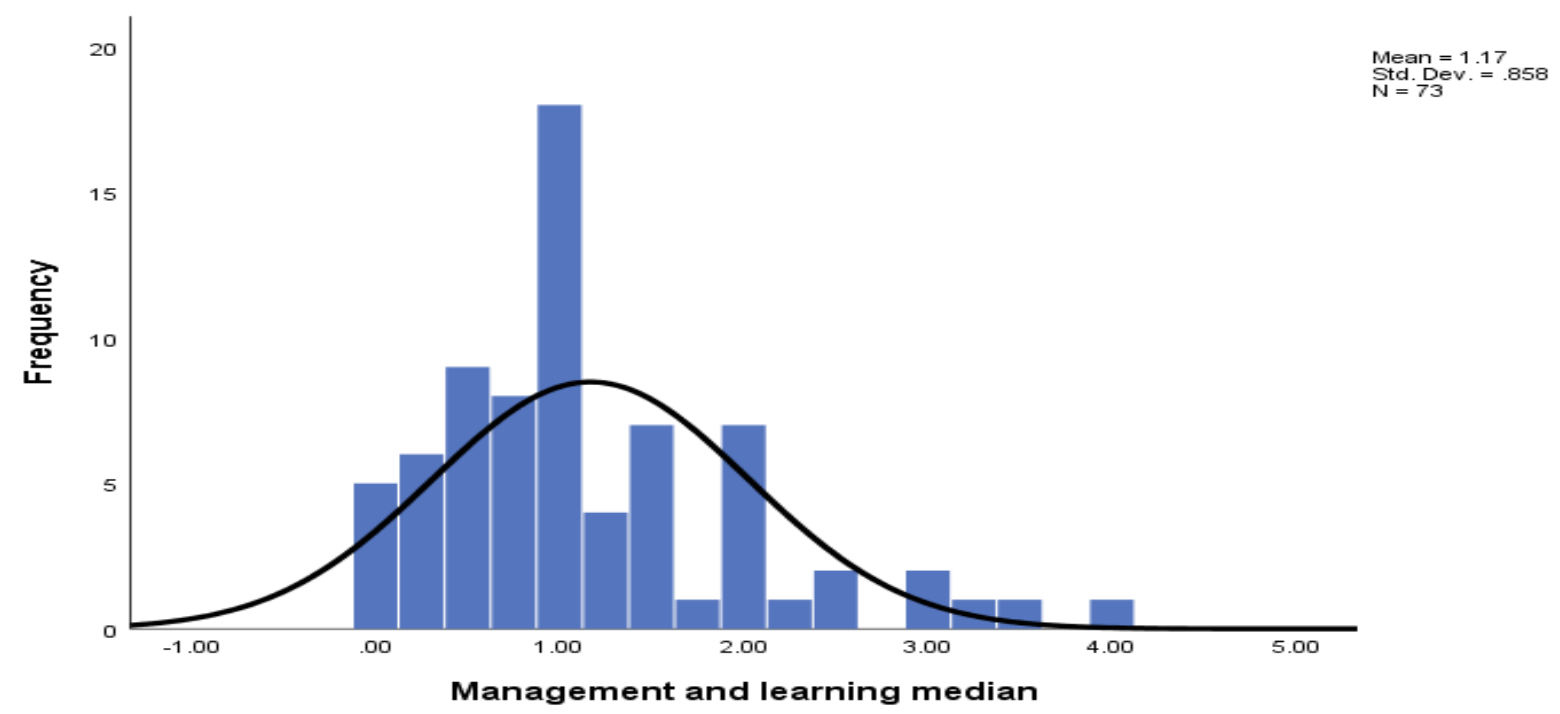

Figure 8 Management and learning culture capacity median histogram, author, field research, 2018

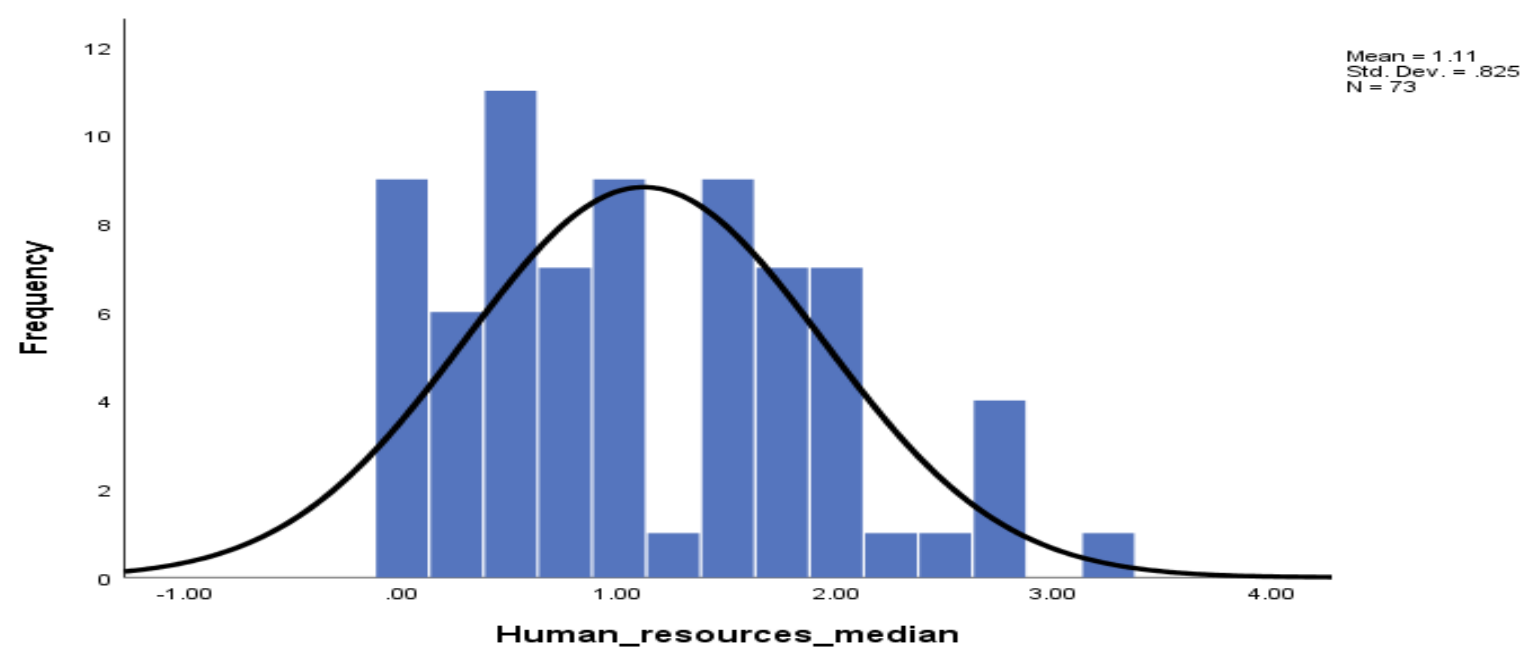




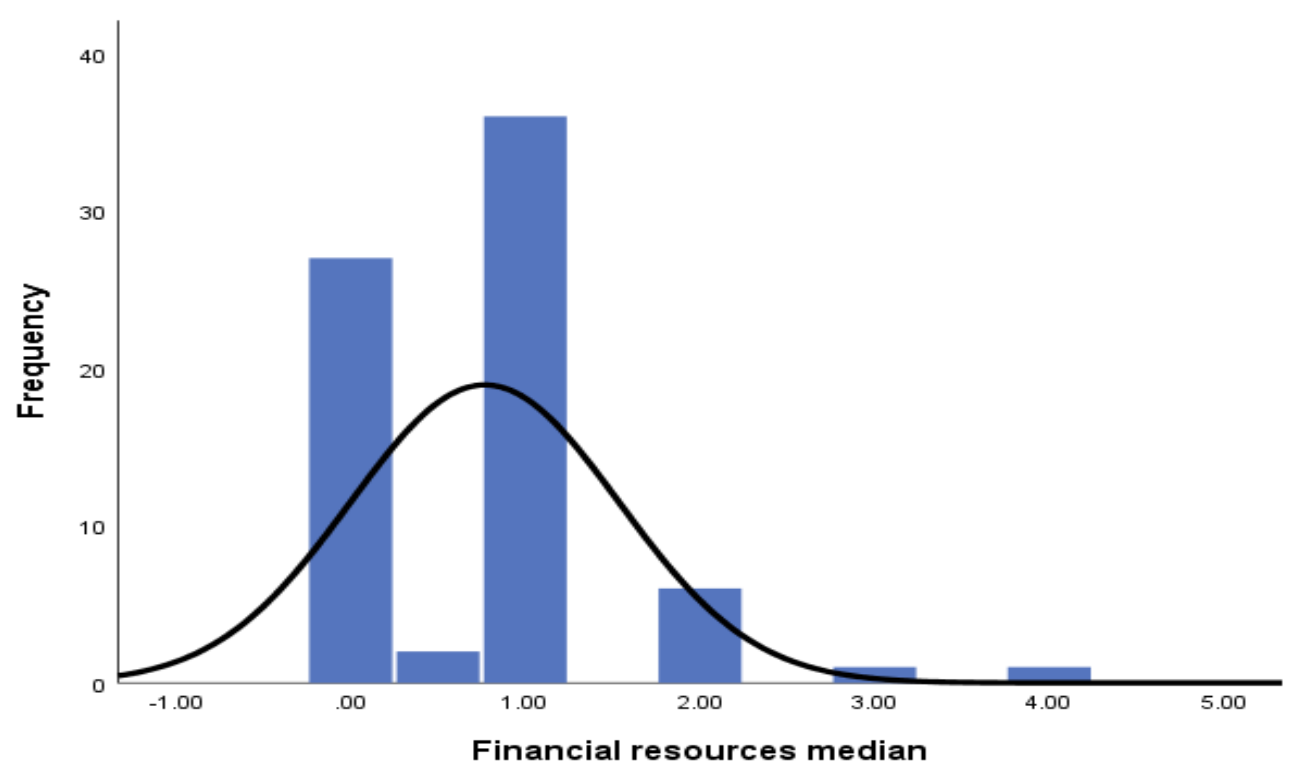

Figure 10 Financial resources capacity median histogram, author, field research, 20180

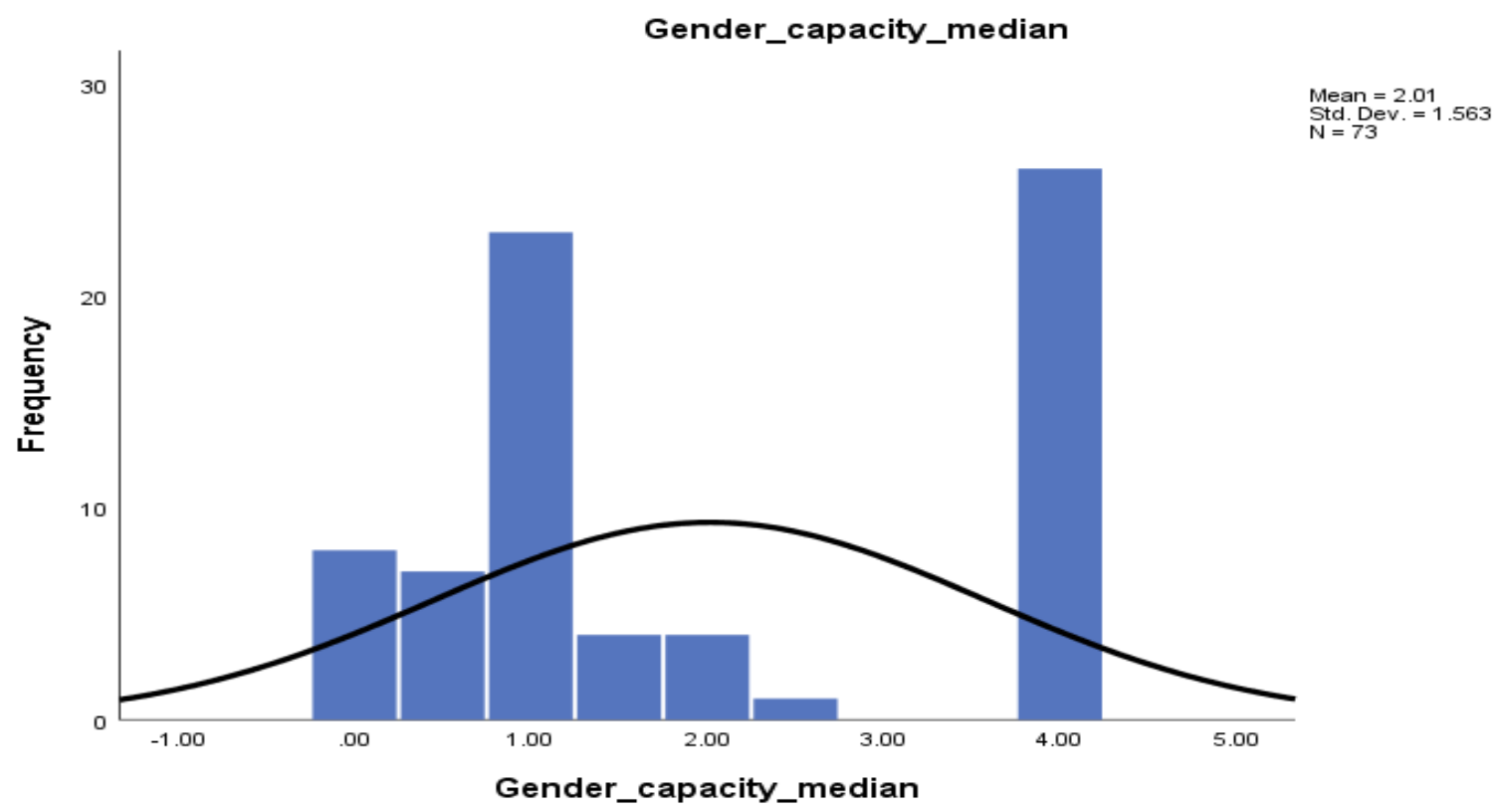

Figure 11 Gender capacity median histogram, author, field research, 2018

Gender related scores were inflated to a mean of 2, firstly because of the default high score given to female-only CSOs who were not asked gender-tracking questions. The reasoning for this was that objectives of sustainable development, CSO capacity and the SDGs included empowerment/agency of women and their control of agenda-setting and decision-making for sustainable development. This was most indicated in women-only groups.

The second reason inflation of gender capacity scores occurred was because those who were asked gave their CSOs high capacity for gender issues. It should be noted that these responses conflicted 


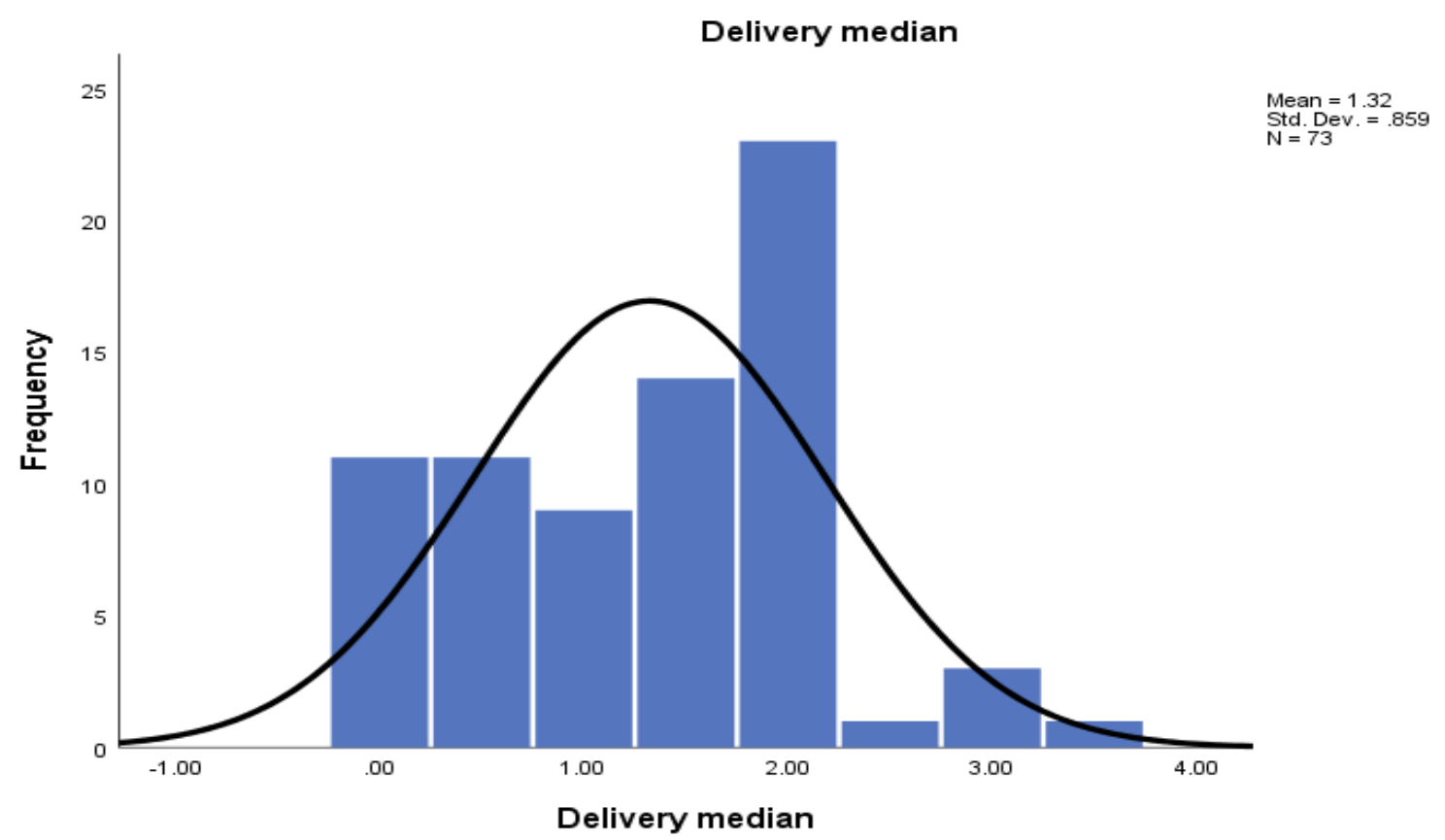

Figure 11 Delivery capacity median histogram, author, field research, 2018

Most notable was how few boards/committees were democratic, and not CEO-controlled. This scored the joint lowest mean score along with the ability to quote the mission statement.

Looking at median scores, the greatest weaknesses were found in;

- staff numbers,

- staff skills,

- number of funding sources,

- CSOs ability to prepare realistic proposals, indicators and logical frameworks,

- development of internal admin systems,

- learning cultures where there was; openness to new ideas \& questioning, overlapping teams, knowledge sharing, identifying root causes, and where leadership involved everyone in decision-making.

This was perhaps the most worrying for capacity building potential. 
Results of Questionnaire 2 - Qualitative - Constraints and SDGs awareness

Respondents were asked open ended questions about which constraints they felt that CSOs faced; things that happened or did not happen to them or their CSO that had affected growth and capacitybuilding, effectiveness, independence, and freedom.

The word cloud below reflects the most frequently mentioned words raised by respondents, with the largest words mentioned most frequently.

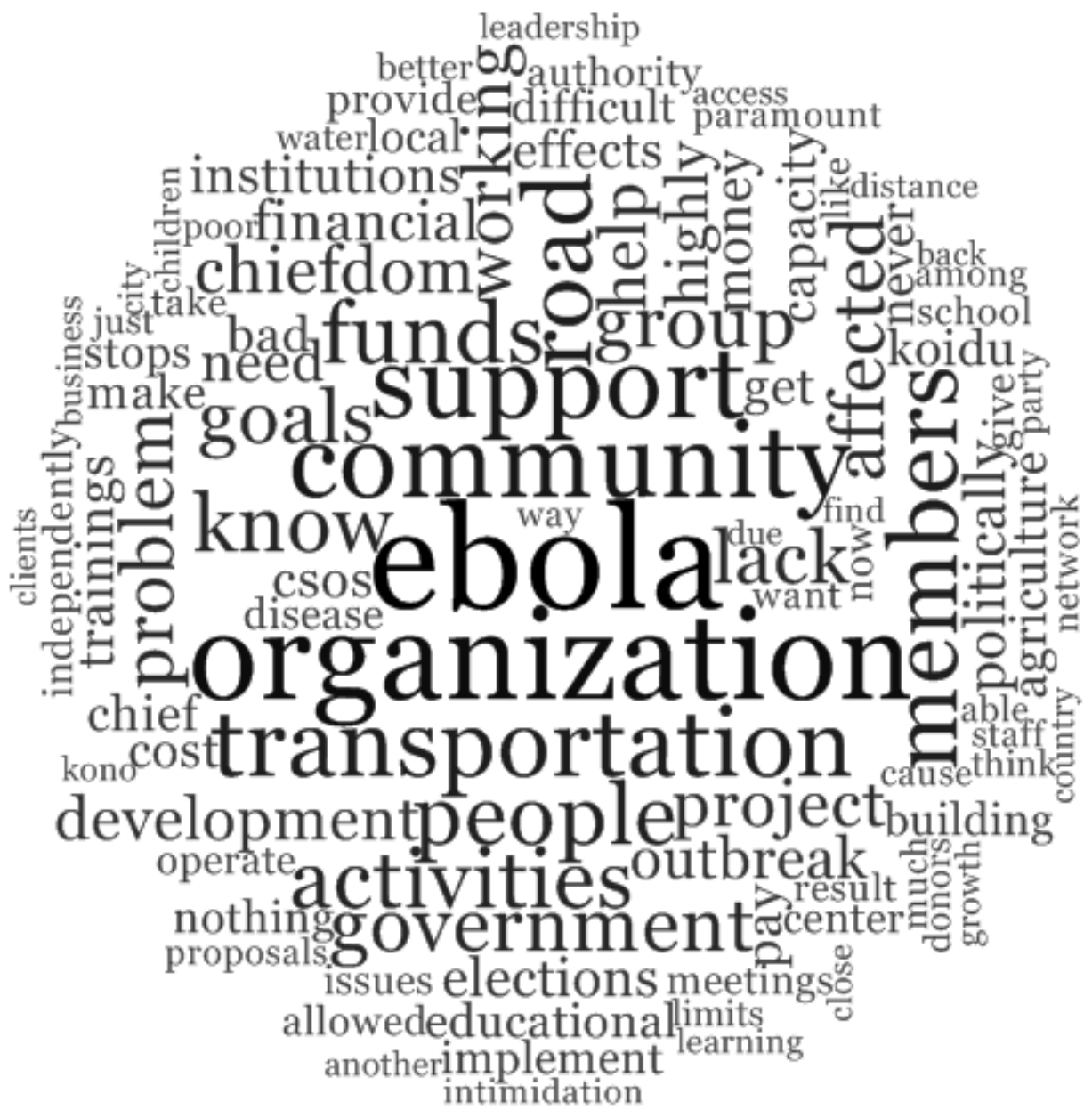

Figure 12 Questionnaire 2 Respondents' Word Frequency Cloud generated in NVivo, author, field research, 2018

Respondents were also asked about their knowledge of the SDGs, their own SDG priorities, and which were the most neglected SDGs in Kono district. 
Predominant themes

When asked which constraints CSOs' faced, themes emerged revealing respondents' preoccupations (Figures 13 and 14). These preoccupations focused on the ebola epidemic, lack of external financial and in-kind support that many respondents felt was the pre-requisite for praxis, lack of CSO-member and community collaboration, lack of equipment and materials, reliance on government and authorities, the effects of power, politics and the 2018 elections on CSOs independence, on empowerment and on the ability to speak to power, geographical marginalisation of rural Kono chiefdoms, low SDG knowledge and attention among CSOs, their communities, local government and development actors.

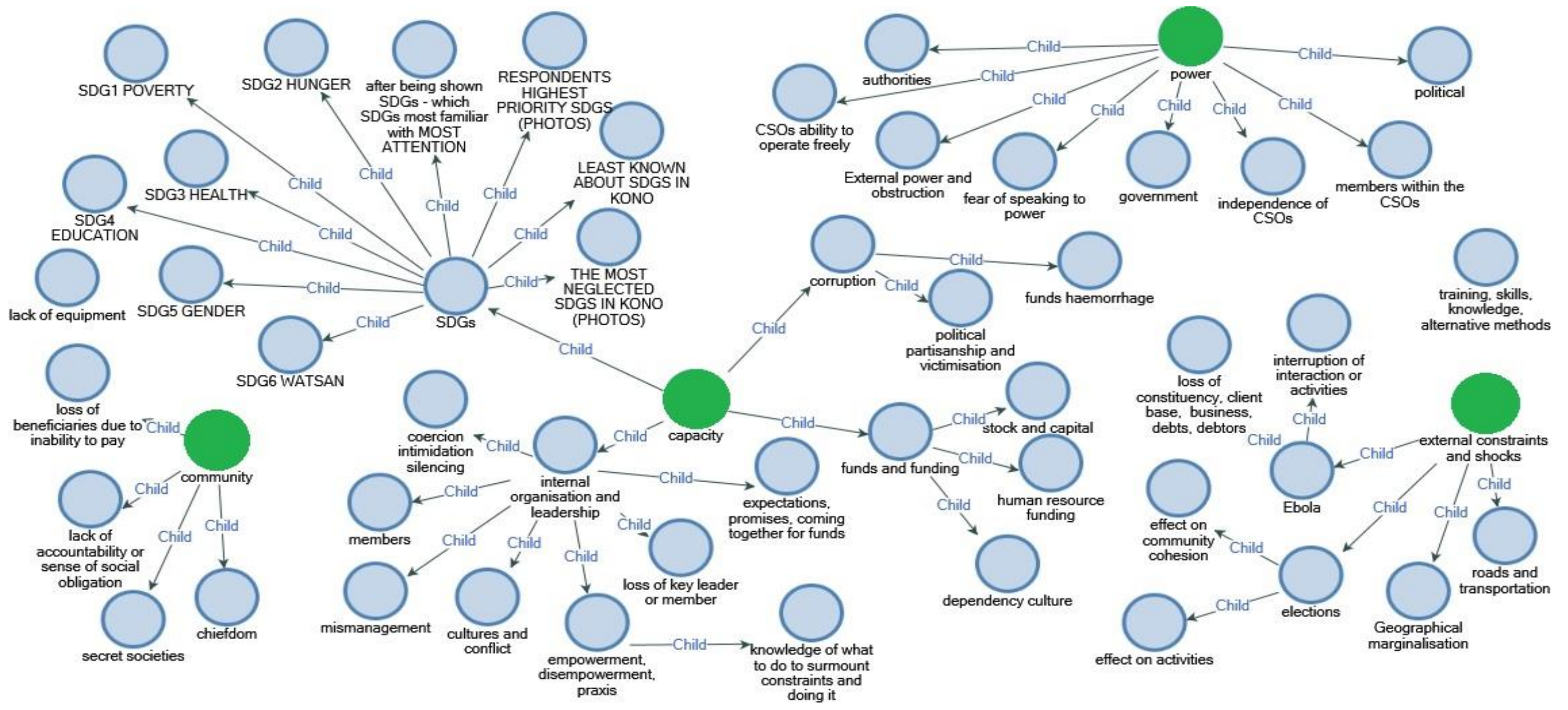

Figure 13 Questionnaire 2 nodes map, author, field research, 2018 
Ebola

The 2014/15 ebola epidemic and state of emergency, froze cooperation and interactivity of CSOs, prevented economic activity and funding and caused some projects and groups to terminate;

"There was no public meetings, no trading was allowed."

"Many NGOs were closed, no project implementation was going on."

"no support was coming during the outbreak" .... "donors withdrew in fear of the disease. That brings down the end of their projects".

"Most organisations closed and some did not even resume again after the Ebola outbreak."

\section{Dependence}

Dependence on external financial and in-kind support and its lack were the main reasons given for organisations' low capacity, effectiveness, cohesiveness and activity. Respondents felt if they received this;

"Group members will also be committed to the group's activities to ensure success."

".... all the members will be in unity and work towards the progress of the group."

"There will be a foundation for the group, and we will surely get $100 \%$ cooperation from all the members."

"there will be no obstruction, in fact lack of all these things was the cause of our disunity."

Over 500 references or synonyms of external financial or in-kind 'support' wanted, needed, lack of, or not forthcoming were made in answer to a variety of constraint-related questions.

"We received no financial assistance from government and other humanitarian organisations."

"We need capacity building and skills training centres, we need financial support to continue our normal activities."

Semantic changes became apparent, illustrating re-tasking of terminology, redirecting attention to respondents' areas of priority with the authority of development language. Stem words of 'Empowerment' that conventionally meant 'power with', 'power to', 'power within', 'power to empower' (VeneKlasen and Miller 2002, Chambers 2013) the disempowered, were instead used to refer to financial support. 'Advocacy', occasionally referred to advocating for funds. 'Support', 'motivation', 'courage' and 'encouragement', were all used in some instances to describe financial support. The word 'stakeholder' may have been used to mean powerholder rather than the full spectrum of stakeholders. Examples included:

"if we are empower with these things, I believe we are going to implement all our project and this will help to improve the group."

"We need to advocate for funds and support so that we can be able to work and change things" 
"Yes, in terms of finance, they (CSOs) have been acting independently, but stakeholders (are) normally involved in the decision-making process."

However, one respondent challenged the dominant belief that external support was a pre-requisite for community and CSO cooperation and praxis;

"Groups should not be 100 percent dependent on donors or government. They should be able to raise funds through contributions and other fundraising activities

Organisations should not die out as a result of a challenge."

\section{Funding}

Funding had impacts on human resources, making it difficult to retain staff, volunteers or members' cooperation.

"We are all unpaid volunteers. It is not easy to volunteer in developing countries as the cost of living is high. So the commitment of members is so low as members have to fend to make ends meet"

"I believe finance and human resources is also a problem for other organisations and because of these, it is much easier to be influence by politics. Some had to play party games to the detriment of these organisations."

“..our volunteers have other commitment."

Debts

Issues with payment of debts by members or beneficiaries arose several times;

"most people normally take debt in the organisation and they never returned back the money.

"Clients are not paying their loans on time and some don't even pay. They are giving us too much stress and headache. Clients are aggressive and abusive when confronted to pay outstanding debts"

\section{Speaking to power}

When asked about fear of speaking to power, some respondents requested anonymity and to talk in private. 46 out of 93 references stated they had seen no evidence of fear of speaking to power, 27 out of 93 references gave identical answers "some of the time", "most of the time" suggesting possible interviewer bias. 17 responses provided deeper insight;

"Community members are afraid to question power holders. For our street solar power, people removed the panel and batteries saying they were sent by the bosses in the office, and the community members don't question those bosses for removing those batteries and panels. It is easy for officials to say this is from "order from above" and nobody questions who is this order from above and why the order."

"The paramount chief stopped our groundnut farming and we were afraid to question his powers. The honourable (member of parliament) treated us badly but we were afraid to face him and ask for our money. The activities of the secret societies have been a problem for us but are afraid to face authorities about it"

"Members failed to question my very self for money which they were expecting but 
was not up to the amount. Instead, they grumbled around until when I called them, later they understood and were OK."

\section{Power politics}

Power politics was an ongoing issue that worsened in the months around elections. There were 66 references to politics and politicians. The March-April 2018 elections were referred to frequently as a constraint;

"The election violence we had didn't only affect us during the period of elections but still have some effects on the group. It almost split the group into two. Imagine we had to spend time to settle those differences between few group members. This didn't help the effectiveness of the group."

"This chiefdom experienced violence before and after the election. We had people killed in election related attacks. We were all afraid and had to cease all activities as a group."

"Some (CSOs) are forced to close or align with political interest groups. Some actually do exist only on paper. Few that are able to resist political influences, do so with much difficulty. "

Actions during the campaigns; damaged community relationships, caused fallouts within CSOs, prompted emigration from the community after the change of government for fear of reprisals, and left CSOs dormant trying to restore operations.

Discussions indicated the presence of latent threat in communities' and in CSOs dealings with power holders, which could have affected levels of fear of speaking to power. In one chiefdom the 'baboon problem' was the public label for suspicious deaths. These had increased in the period leading up to the elections.

"The frequent baboon attack and killing of innocent people in xxxxx Chiefdom should be properly investigated and put to a rest as I strongly believe there are people behind it, especially the leaders. I am not going deeper into this."

\section{Government}

Government was referred to 107 times, often in the context of, assistance or performance of responsibilities to respondents' communities, government partnerships with NGOs, paramount chiefs, CSO dependence and independence, and needing permission to act.

"The Paramount Chief owns the chiefdom. He is the custodian and his sub-chiefs permit us to operate. The government owns the country. So if they don't want any group, the group will not exist. So they (CSOs) are dependent on them one way or the other"

These sentiments reflecting a perception of government and chiefs' absolute entitlement - if widely held by rural communities - could inhibit their, and by extension their CSOs, feelings of entitlement to claim rights to development and social justice.

\section{Geographical marginalisation}

Geographical marginalisation, remoteness, roads, neglect, exclusion, transportation difficulties and costs affected capacity and participation in CSOs especially in chiefdoms away from the district capital, Koidu. Those in outer chiefdoms strongly expressed their exclusion and feeling of being disregarded and neglected by district authorities, central government and international donors. Some 
in Koidu expressed mild worry for those in remoter areas. Project funding not being made available to remote rural groups was an issue and also affected CSO capacity and growth.

"in the first place, the UNDP should allow CSOs to bring up proposals for new project and they should be funded. Also, the UN should decentralise projects to the rural areas in our communities."

"A very huge problem for us and people in Koidu. For us here to Koidu transport fare is Le 30-40,000 per person one way (£3-£4, about 2 days' wages). The road are not good and not too favourable for low cars, and for you (interviewers) who are first time riders in places like this you will soon experience the challenge and effect on you as well, please don't forget to let us know about it (laughter). It's been a very long time since we stopped receiving invitations from other communities to help in community development, but we have such plans as we progress."

The schadenfreude ${ }^{3}$ above served to illustrate not only CSOs' and communities' backbreaking journeys on motorbikes taking 3 hours or more, but also an extra price; the injuries and pains they get to keep in the aftermath of every journey.

"The distance is not far, but the road is rough which cause the transport fare to go high. This causes lateness or non-attendance of meeting by members. Members will deliberately not pay their huge money just to volunteer for the good of the community"

"That is why whenever they call us for meetings in other chiefdoms we only send one person to represent us."

"I believe that it is because of the distance and bad road the most people don't come to our aid."

\section{Internal constraints}

Internal organisation emerged as a theme more notable for absence of mention when respondents were asked to think of constraints. Some blamed lack of unity and cooperation, a few said 'capacity building' was needed but only in the context of external support and funding.

81 references shared more in-depth insights about what they felt were the kinds of actions that were needed:

- Attitude-change of INGOs and UNDP towards rural CSOs and better commitment (longtermism)

- Training and workshops,

- Prevention of government, politician, chiefs and secret societies' influence over CSOs or intimidation,

- Avoidance of CSO political partisanship,

- More female inclusion and leadership,

- Sustainability of programmes and of financial planning,

- Financial self-sufficiency and raised skills capacity of CSOs,

\footnotetext{
${ }^{3}$ Humour gained from someone else's discomfort, in this case humour as found in the fact that a common unpleasant experience of communities was about to become a shared experience with interviewers.
} 
- Programme planning, upskilling and drafting,

- Meritocracy within CSOs,

- Adequate prosecutions for corruption in CSOs including restitution of funds, fines and imprisonment,

- Regular meetings and strategic planning,

- Community backing,

- Effective early conflict management,

- Cattle controls to protect farming communities, and

- More research on capacity and constraints of local communities and finding solutions to capacitate them"

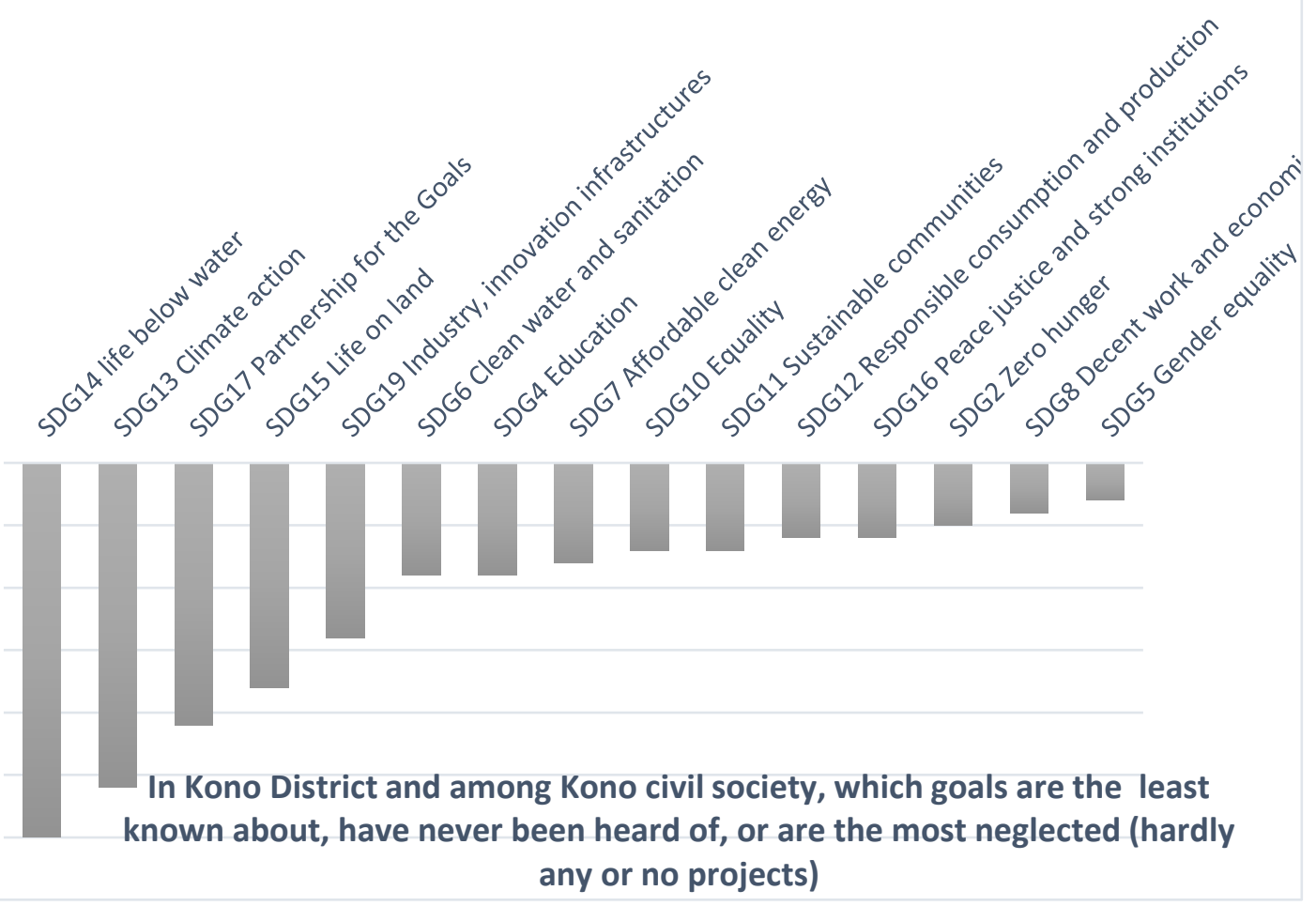

Figure 14 - SDGs least known about, never heard of or most neglected, author, field research, 2018

Many CSO respondents were unfamiliar with the SDGs. Several had one or more themes in mind. $15 \%$ showed evidence of SDG training or attending workshops. Only a handful were quite knowledgeable;

"... the things that we should fight if we are to live a better life as humans. I heard it from the last workshop I attended."

"...to be looked at by organisations and communities to bring development"

".....due to the facts that we have not been able to achieve these (Millennium Development) goals, the 8 pillars have been divided in to 17 goals so that organisations can easily fit in." 
"They were formed by the United Nations. They must be prioritised by institutions and development partners"

"We were told by $x x x x x$, a CSO in Sierra Leone, in a workshop about most of these goals. Some are talking about deforestation and its negative impacts, good governance, peace building etc. I know that they are the yardsticks for sustainable development."

The contrast between the majority of respondents' SDG knowledge and a select few was striking. However, once shown the SDGs, respondents were highly familiar with many of the concepts.

Respondents highest SDG priorities for Kono District were overwhelmingly concentrated at one end of the SDG spectrum in just four areas;

- SDG1 poverty,

- SDG2 hunger,

- SDG3 health and

- SDG4 education.

This indicated ghettoization of sustainable development efforts and thinking for Kono District, restricting most action and awareness to one fraction of the sustainable development spectrum.

Conversely the SDGs least known, never heard of or most neglected were;

- SDG14 life below water,

- SDG 13 climate action,

- SDG17 partnerships for the goals,

- SDG15 life on land.

- SDG19 sustainable industry, innovation, and infrastructures

\section{Discussion}

\section{Overview}

This study provides a snapshot of systemic and social systems in various states of flux, relying on CSO actors' own perspectives and on previous studies.

Quantitative results indicated Kono CSOs had extremely low capacity across all areas, in all chiefdoms. To become effective, CSOs will need to invest significant effort and energy into capacitybuilding.

Outlying chiefdoms further away from the district capital Koidu, expressed more neglect and exclusion from the sustainable development agenda, from decision-making and from funding, than those within Koidu.

The district capital had a high concentration of CSOs; some of whom served communities in outlying chiefdoms. Many chairs of the latter were resident in Koidu away from their target constituencies and members. Communication and travel to and fro in order to conduct CSO activities was constrained by high telecommunications and travel costs and poor roads. 
Respondents were mostly focused on external constraints - especially lack of external support, with little introspection into their own CSOs' internal capacity, cultures, values, preparedness, processes, systems or trustworthiness. However some provided insight into other CSOs' internal constraints.

The themes that emerged were;

- the ebola epidemic of 2014 - 2015

- lack of, and dependence on, external financial and in-kind support

- lack of equipment and materials

- reliance on government and authorities

- positioning of external support as the precondition for spontaneous community praxis

- lack of member and community commitment, cohesion and inter-cooperation

- importance of trust-building and conflicts

- effects of power, politics and the 2018 elections on CSOs independence, fear of speaking to power and ability to act (empowerment)

- geographical marginalisation of rural Kono chiefdoms

- low SDG knowledge or attention among CSOs, communities, local government and development actors

- over-concentration of knowledge and power in a few key individuals, resulting in CSOs' collapse when those individuals left or passed away

- lack of long-termism, among donors, district sustainable development interventions, strategies and funding, and among some CSO CEOs.

\section{CSO Human resources and motives}

Human resources presented a fundamental problem, and almost all respondents' CSOs had no paid staff, relying on volunteers with limited skills. Staff numbers in remote rural settings have to be judged against the likelihood of having sustainable operations-funding to pay for them. This is hard to acquire without long term, diverse-funding plans, systems, investments and income streams, which take time to build up, and which no CSO claimed to have in place.

CSOs are further handicapped by new controversial regulations compelling them to ensure $70 \%$ of donor funding reached beneficiaries (GoSL, 2018) limiting further the amount available for operations. It follows that even after significant self-capacity building, rural CSOs will be dependent on volunteers and unlikely to have enough personnel for separation of management and strategic governance roles. This will affect future CSO transparency, accountability, planning and oversight.

Competing priorities for survival and livelihoods, plus distrust and disinterest, pulled potential participants away from community activities. Respondents referred to mismanagement of organisations and funds and domination of decision-making, further serving to alienate participants. Responses suggested that communities', donors', politicians', chiefs', members' and beneficiaries' trust in CSOs was low, and indicated diminished public spiritedness and altruism plus reluctance to invest in ventures that lacked immediate personal benefit. Observations of the wider community and Diaspora also indicated reluctance to expend energy to enhance the status or wealth of single individuals or political opponents.

To attract collaboration and funding, community and donor trust will first need to be created by the CSOs. However several respondents demonstrated expectation and desire for unconditional trust to be given to them and gave no indication of their efforts or intentions to build trust. 
Ironically, trust-building will require communities to be ready to volunteer, learn, and create good organisational cultures, systems, democratic decision-making and guaranteed common ownership of CSOs. The psychology and sociology of precarious rural communities (Bateman, 2017), their priorities and decision-making on where to invest their time and effort is relevant here. Risk-averse rural communities are more likely to invest in failsafe, self-tested, utilitarian advantage than altruism or promises, so expectations of regular substantial efforts into community affairs that are full of risk, never failsafe, and require sacrifice of time or risk strategies, are unrealistic. Respondents' protests to interviewers about their time and sacrifice supported this.

For spontaneous community praxis to manifest itself for anything but the most urgent crisis, rural communities may need to bypass utilitarian motives and access emotional priorities. The SDGs for example, could be marketed as a trust-building cause to rally emotions around, as a holistic ally of rural communities that is concerned about often-neglected needs, and as a global club of excluded communities around the world that they are invited to join. Development interventions in Kono district tend to be national and sector based, trickling down limited centralised resources to a few sectors; often the same few. This was reflected in respondents' higher awareness of SDGs 1 to 5 and lack of knowledge of SDGs 13, 14, 15 and 17. Respondents' greater awareness of SDG 16 may be a result of Sierra Leone's experience of internal conflict for most of the 1990s, its long-term history of corruption and issues with law and order.

The 17 SDGs cross sectors that are often neglected by local-development actors, and they provide a holistic framework to measure progress. Mobilisation behind the SDGs could mitigate exclusion and isolation expressed by Kono CSOs in reaction to ignored needs, and could inspire motivation and rural communities' feeling of connectedness with the outside world.

\section{Trust building}

CSOs were not trusted, but they have the potential to be more trusted than government agencies, as was the case in Ghana (CIVICUS 2014). Respondents' expectations of unconditional trust and investment implied they were aware it was lacking and necessary, but not that they would be the ones to actively build it.

Building public trust in individual members requires them to be trustworthy, preferably altruistic. If that fails, another strategy is to build public trust in the institution not the individual. This requires unassailable checks and balances and guarantees of democratic community ownership and governance, uninfluenced by outside forces. This is trust born out of the removal of wriggle room for the individuals within it, extreme transparency, and being held to account by community members who feel entitled. There are indications of appetite for this, such as in the 2018 general elections where the public became extremely active, sensitised and watchful for signs of corruption at the polls; using social media to 'out' suspect activities. CSOs choosing this strategy would have a competitive marketing advantage in persuading communities and donors of their trustworthiness.

Financial conflicts have occurred and are at high risk of occurring. Community members were afraid to face up to power holders within CSOs to insist on exercising their decision-making powers or to enforce accountability. The will of community members to speak to power is essential for strong financial management and to mitigate; lack trust from communities, members and donors, co-option of finances, of ownership and agenda-setting, poor transparency and democracy, reluctance to participate, etc. Financial management and long-term financial planning will be essential for any CSO wishing to start trust-building.

\section{The SDGs and the local development agenda}

Another avenue already mentioned above is education of communities and all local stakeholders on the SDGs, which respondents expressed considerable interest in. The SDG targets and indicators can give communities' a big picture of what holistic sustainable development looks like at local level, guide tracking and monitoring, focus the districts development agenda, and assist tailoring of locally 
relevant, credible funding proposals. Partnerships for the goals (SDG17) provoked a response, showing the potential to create hope for rural communities that they could be an active part of the Partnerships. The Partnerships could also empower communities to speak locally to power on the national SDG agenda. CSOs' eagerness to learn about the SDGs and have this knowledge spread to development actors, demonstrated their role as knowledge brokers.

\section{Practicability of learning}

Respondents suggested their CSOs had a good learning culture, but few had functioning democratic boards, which casted doubt on whether CSO leaders were indeed pro-empowerment, ready to be questioned and taught by subordinates. Communities need to be receptive to learning organisational skills and volunteers need to be skilled and prepared to deliver management skills in the evenings. In an agricultural rural setting, the hours of work necessary to learn and practise management systems may make it impracticable; respondents protested to interviewers at the sacrifice of time taken away from daily rural duties and suggested there was more available time for community activities in the dry season.

\section{Traditional architypes}

Empowerment has been a source of conflict, including in the Kono Diaspora. This could be explained by attempts of CSO leaders to apply widely-understood chieftaincy-type pyramid governance models within CSOs. The original principles of CSOs include collective, egalitarian, democratic praxis and service to beneficiaries (akin to a round table). The chieftaincy model was therefore inappropriate for chairs/CEOs who sometimes accepted the title 'mansa' (chief). It prevented empowerment of boards and committees unless committees empowered themselves. With disempowered committees, oversight and accountability became difficult; chairs/CEOs were allowed unrestricted and often unchallenged disposal of donated resources. Catastrophic breakdown of organisations often followed.

\section{Political co-option, influence and power relations}

An enabling environment for CSOs depends on CSOs being allowed and encouraged to carry out their many functions unhindered including monitoring, advocacy, and holding to account, and it relies on CSOs being able to maintain their independence from undue influence, infiltration and co-option by political parties and power holders. It depends on existing and constructed perceptions within and outside of CSOs amongst chiefdom communities, councils, businesspeople, chiefs and politicians. Political partisanship of CSOs was a constraint raised by respondents, however this may simply obscure a constructed dichotomy paradigm. Critics have depicted CSOs as separate from society and analogous to opposition political parties (Kanu, 2016). Separating CSOs from the communities they were made of created paradoxical views in the minds of proponents, opponents, and spectators. An example of this paradox was illustrated by a Diaspora CSO chair who stated to a large network of Kono-based CSOs that the Kono Conference they were all organising had nothing to do with civil society. This study's CSO respondents included farmers, women, microfinance savings and loans groups, produce marketing groups, development groups, youth groups, okada (taxi bikes) bikers' unions, school alumni, mothers clubs, church groups, community radio organisations, vocational training organisations, youth road repair gangs, etc. Respondents rebutted the supposed dichotomy paradigm when they revealed that, especially in rural communities, both communities and beneficiaries were civil society and vice versa. Nevertheless, this argument has often been used by political opponents to undermine public perception of CSOs, NGOs and 'civil society' in Sierra Leone.

The 2018 elections affected CSOs in the months preceding the elections, with significant mention of violence, coercion within and without CSOs, intimidation and homicides. This affected the ability of CSOs to meet and carry out activities. Some CSO members and leaders took sides in the elections and coerced others. Discussions revealed background pressures that existed all year round to compromise the independence of CSOs, with both latent and active influence exercised by power holders.

Demanding transparency and accountability or democratic decision making has resulted in allegations 
of disrespect to power holders and trying to supersede authority. This can increase a fear of speaking to power, which was shown in this study to exist in Kono district, and is likely to deter against strong rights advocacy, creating 'neutralised, depoliticised and instrumentalised' CSOs (Datzberger, 2014, p3). Inferences may be drawn about the effect of requiring permission for any action even at family level and expecting to be stopped, on praxis, on people's power within, power with and power to (VeneKlasen and Miller 2002, Chambers 2013) speak to power.

Respondents provided evidence of significant influence on CSOs by chiefs, politicians, CEOs, social norms and power balances, confirming allegiances existed and were acted upon. Some denied existence of power pressures but respondents were aware of influences and reluctance to speak to power. Disparity in power and control within CSOs was demonstrated by; the effect of removing key players, development of organisational structure, and the large number of chair/CEOs, and buttressed previous studies findings of elite capture of CSOs. This was also supported anecdotally. People are often sceptical of CSOs believing them to be working for outside influences. It should be noted new elite are constantly created through education, knowledge, skills, mobility, contacts, exposure, positions, and wealth.

Council-CSO partnerships and alliances (GTLRG, 2018) reveal a route to mitigation of elite capture and increased capacity for the SDGs in Kono. A localisation triumvirate of Council, CSOs and Paramount chiefs could go even further to catalyse attitudinal change necessary and mitigate Labonte's (2011) elite/non-elite power imbalances. The Chiefs would find SDG localisation allies in both local councils and CSOs.

\section{The rural / geographical divide}

Respondents were highly conscious that sustainable development tends not to make it as far as their rural villages. However, CSOs largely felt powerless to do anything to change this, increase their agency in development matters and change power relations between themselves and their Koidu based chairs. Localisation efforts need to be reoriented from a top-down approach where such discourse is just arriving and permeating at district level, to a bottom-up approach where chiefdom development plans are collated into district programmes.

In addition to geographical marginalisation, the digital divide was in evidence and experienced by interviewers. Lack of access to affordable and reliable ICT connectivity and communications added to marginalisation and exclusion of rural communities from development activities;

"Active community members need to interact with each other, with CSO's, institutions, Diaspora CSO's, NGO's and donors, they need to take part in meetings, teleconferences and live-streamed conferences, solve problems together, capacity build their organisations, mobilise, access and share knowledge and other resources, collaborate on project delivery etc, but cannot because of very high call and data costs and very low bandwidth in Sierra Leone. Diaspora potential partners have found it incredibly difficult to help mobilise local communities or form effective partnerships because of this." (Author, 2017)

\section{Conclusion}

In Kono District, communities have traditionally accepted the top-down approach as the norm; looking to politicians, government, chiefs and local councils for development and patronage.

However, they are also highly familiar with the tenets and practices of participatory community praxis as a stable foundation of sustainable development. For this to happen, communities with low levels of organisational management skills and high levels of outside dependency, must be prepared to maintain their ethics and altruism so as to keep working relationships cohesive and productive and to regain their reputations for trustworthiness. 
Power relations and trustworthiness within and outside of CSOs still play a large part in preventing praxis from happening, especially because communities continue to show reluctance to claim their rights and speak to power.

Ironically, empowered communities protected from resource capture, would be more likely to celebrate the leaders that made this possible. Secure communities whose resources are safe, are likely to feel empowered to invest more time and effort into civil society activities, boosting local productivity, sustainable land management, chiefdom development and stability rather than instability.

Local communities' social awareness and the conditions they live under have created a high level of enthusiasm for change. This suggests a high likelihood that removal of the internal and external constraints found in this study could create the necessary conditions for CSO capacity building and swift progress on the Sustainable Development Goals.

\section{References}

Acemoglu, D., Reed, T. and Robinson, J.A., (2014) "Chiefs: Economic development and elite control of civil society in Sierra Leone". Journal of Political Economy, 122(2), pp.319-368. - accessed 6 jan 2018

African Civil Society Circle (2016) "Position Paper: The Roles of Civil Society in Localising the Sustainable Development Goals". Democracy Development Programme. Available at http://www.acordinternational.org/silo/files/the-roles-of-civil-society-in-localizing-the-sdgs.pdf

Albrecht, P. (2017). The Hybrid Authority of Sierra Leone's Chiefs. African Studies Review, 60(3), 159-180. doi:10.1017/asr.2017.87

Bateman J (2017) Rural Livelihoods in Sierra Leone: Longitudinal Insights from Panguma and Kayima. Thesis PhD University of Otago, NZ.

Beekman G, Bulte E, Peters B Voors M (2015) “CSOs in Liberia and Sierra Leone during the ebola epidemic" Development Economics Group - Wageningen University

Binns T (1980) 'The dynamics of third world food production systems - an evaluation of change and development in the rural economy of Sierra Leone'. PhD Thesis, Centre of West African Studies, University of Birmingham.

BOND (undated) [online] Organisational Health Check available from https://www.bond.org.uk/ngosupport/organisational-health accessed 3 April 2018

(CGG) Campaign for Good Governance (2007) “CIVICUS 2007 Sierra Leone CSI CIVIL SOCIETY INDEX -Report". CIVICUS.

(CGG) Campaign for Good Governance (2014) “CIVICUS 2014 Sierra Leone CSI-Rapid Assessment report". CIVICUS

Chambers R 2013 [video][online] The elephant in the room. Available from

https://vimeo.com/user13958607/review/70933318/691547376b IDS Sussex University PLAN

International. accessed 12 September 2018

CIVICUS (2018) Monitor (BETA). Sierra Leone. [online] Available at:

https://monitor.civicus.org/country/sierra-leone/

CIVICUS (2014), Civicus Civil Society Index - Rapid Assessment, West Africa Regional Report, WACSI. 
Critical Ecosystem Partnership Fund (CEPF) [online] (undated) Organisational Capacity Tracking tool. Available from: https://www.cepf.net/impact/monitoring-and-evaluation/grantee-role-cepfglobal-indicators accessed 11 July 2018

Critical Ecosystem Partnership Fund (CEPF) [online] (undated) Gender Mainstreaming Tracking tool. Available from: https://www.cepf.net/impact/monitoring-and-evaluation/grantee-role-cepf-globalindicators accessed 11 July 2018

Simone Datzberger (2015) Peace building and the depoliticisation of civil society: Sierra Leone 200213, Third World Quarterly, 36:8, 1592-1609, DOI: 10.1080/01436597.2015.1043990

Erdmann G \& Engel U (2007) p26 "Neopatrimonialism Revisited - Beyond a Catch-All Concept" German Institute of Global and Area Studies Research Program

Fanthorpe R and Maconachie R (2010). Beyond The 'Crisis Of Youth'? Mining, Farming, And Civil Society In Post-War Sierra Leone. African Affairs, 109(435), 1 April 2010, pp251-272

Friere P $(1968,1993,2005)$ Pedagogy of the Oppressed Ch 2-3. New York. Continuum International Publishing Group Inc available at: http://commons.princeton.edu/inclusivepedagogy/wpcontent/uploads/sites/17/2016/07/freire_pedagogy_of_the_oppresed_ch2-3.pdf

Global Taskforce of Local and Regional Governments (GTLRG) (2018). Towards the Localisation of the SDGs. LOCAL AND REGIONAL GOVERNMENTS' REPORT TO THE 2018 HLPF. UNDP p10 available at https://www.global-taskforce.org/sites/default/files/2018-

07/Towards the localization of the SDGs.pdf

GoSL Government of Sierra Leone (2015) p15 "2015 Population and Housing Census summary of final results". Statistics Sierra Leone. Freetown.

GoSL Government of Sierra Leone (2016), p55 "Advanced Draft Report on Adaptation of the Goals in Sierra Leone". Freetown

Ibrahim A.F. \& Majeks-Walker, N. (2015) p165, Civil Society and Development in West Africa: Practitioners' Perspective - Sierra Leone section. WACSI, OSIWA.

International Centre for Not for Profit Law (ICNPL) (2018) [online] Civic Freedom Monitor: Sierra Leone. Available at http://www.icnl.org/research/monitor/sierraleone.html accessed 24 July 2018

Johnston-Taylor N (2015). "The resource curse and natural resource environmental governance in Sierra Leone: case study Kono District". Thesis PhD University of Leeds.

http://etheses.whiterose.ac.uk/9315/ (Accessed 212 2018)

Kanu K (2016) [online] 'Civil society organizations are the Opposition SLPP in disguise: A very troubling trend in Sierra Leone', Cocorioko, USA, 21 November 2016, available at:

http://cocorioko.net/civil-society-organizations-opposition-slpp-a-very-troubling-trend-in-sierraleone/ accessed 15 August 2018

Kanyako V (2011) "The Check Is Not in the Mail: How Local Civil-Society Organizations Cope with Funding Volatility in Postconflict Sierra Leone".Indiana University Press, Volume 58, Number 2, Winter 2011 pp. 2-16

Labonte M T (2011) "From Patronage To Peacebuilding? Elite Capture And Governance From Below In Sierra Leone”. African Affairs, 111(442) (January 2012), pp90-115. OUP for Royal African Society.

Mo Ibrahim Foundation (2017). Ibrahim Index of African Governance (IIAG) 2017 Index Report. Mo Ibrahim Foundation. [online] Available at: http://www.moibrahimfoundation.org/iiag/ [Accessed 8 September 2018]

OHCHR (2018) Mandates of the Special Rapporteur on the promotion and protection of the right to freedom of opinion and expression; and the Special Rapporteur on the situation of human rights 
defenders. Available at

https://www.ohchr.org/Documents/Issues/Opinion/Legislation/OL SLE 22.02.2018.pdf

Omede A, Bakare A (2014) "The Impact of Civil Society Organizations on Sustainable Development in Developing Countries: The Nigerian Experience". African Research Review 8 (1), Serial No. 32, January, 2014:205-227

Fulu E, Jewkes R (2007) Quantitative Male Interviewers Training Manual. Partners for Protection, based on Watts and Jansen (2007) Supervisor's Manual. WHO

Shapiro S and Wilk M. (1965) An Analysis of Variance Test for Normality (Complete Samples) Biometrika Vol. 52, No. 3/4 (Dec., 1965), pp. 591-611

UNDP (2016) p4 Sierra Leone Briefing note for countries on the 2016 Human Development Report. UNDP

VeneKlasen, L. and Miller, V. (2002) Ch.3. A New Weave of Power, People \& Politics: The Action Guide for Advocacy and Citizen Participation, World Neighbours, Oklahoma City. 